Review

\title{
Probing Structural Dynamics of Membrane Proteins Using Electron Paramagnetic Resonance Spectroscopic Techniques
}

\author{
Indra D. Sahu 1,2,* and Gary A. Lorigan ${ }^{2, *}$ \\ 1 Natural Science Division, Campbellsville University, Campbellsville, KY 42718, USA \\ 2 Department of Chemistry and Biochemistry, Miami University, Oxford, OH 45056, USA \\ * Correspondence: idsahu@campbellsville.edu (I.D.S.); gary.lorigan@miamioh.edu (G.A.L.); \\ Tel.: +1-(270)-789-5597 (I.D.S.); +1-(513)-529-3338 (G.A.L.)
}

Citation: Sahu, I.D.; Lorigan, G.A. Probing Structural Dynamics of Membrane Proteins Using Electron Paramagnetic Resonance Spectroscopic Techniques. Biophysica 2021, 1, 106-125. https://doi.org/ 10.3390/biophysica1020009

Academic Editor: Luciano A. Abriata

Received: 19 February 2021

Accepted: 23 March 2021

Published: 30 March 2021

Publisher's Note: MDPI stays neutral with regard to jurisdictional claims in published maps and institutional affiliations.

Copyright: (c) 2021 by the authors. Licensee MDPI, Basel, Switzerland. This article is an open access article distributed under the terms and conditions of the Creative Commons Attribution (CC BY) license (https:// creativecommons.org/licenses/by/ $4.0 /)$.

\begin{abstract}
Membrane proteins are essential for the survival of living organisms. They are involved in important biological functions including transportation of ions and molecules across the cell membrane and triggering the signaling pathways. They are targets of more than half of the modern medical drugs. Despite their biological significance, information about the structural dynamics of membrane proteins is lagging when compared to that of globular proteins. The major challenges with these systems are low expression yields and lack of appropriate solubilizing medium required for biophysical techniques. Electron paramagnetic resonance (EPR) spectroscopy coupled with site directed spin labeling (SDSL) is a rapidly growing powerful biophysical technique that can be used to obtain pertinent structural and dynamic information on membrane proteins. In this brief review, we will focus on the overview of the widely used EPR approaches and their emerging applications to answer structural and conformational dynamics related questions on important membrane protein systems.
\end{abstract}

Keywords: embrane protein; electron paramagnetic resonance (EPR); site-directed spin labeling (SDSL); double electron electron resonance (DEER); structural topology and dynamics

\section{Membrane Proteins}

Membrane proteins are very important biological systems responsible for biological functions vital to the survival of living organisms [1,2]. Membrane proteins represent targets of more than $50 \%$ of modern medical drugs. They represent one third of total protein found in the living organism. Membrane proteins associate with membrane bilayers in the form of single pass transmembrane, multi pass transmembrane, lipid chain-anchored, glycosylphosphatidylinositol (GPI) anchored, and membrane peripheral proteins [3]. Mutations or misfolding of membrane proteins are linked to several human health related issues. Understanding of intermolecular interactions, protein functions, and regulations requires detail studies of structural and dynamic properties of membrane proteins [4-6]. Despite the clear biological importance of membrane proteins, in-depth information about these systems are inadequate [7,8]. Membrane proteins make up less than $1 \%$ of the known protein structures [9]. In recent years, great efforts have been made in structural biology to investigate membrane protein structures [10]. The challenges in studying membrane proteins arise due to their hydrophobic behavior that causes low protein expression yield, and the requirement of membrane solubilization limiting the application of several different biophysical techniques [6,11]. Membrane proteins are reconstituted into lipid bilayers in various different manners or orientations. The helical regions buried in the membrane bilayers can have different length or it can be curved in the middle of the membrane bilayers. They may cross the membrane at different angles, or form re-entrant loops or stay flat on the membrane surface. This may cause certain membrane protein segments to be very flexible while other sections more stable in specific conditions [3]. Our current 
understanding of structure and conformational dynamics of membrane proteins is lacking behind when compared to that of globular proteins.

In order to understand the structural and functional relationships of membrane proteins, it is important to study membrane proteins in a native membrane environment. There are several membrane mimetic systems available for the solubilization of membrane proteins for biophysical studies. However, no membrane mimetic systems are universally compatible to all membrane proteins requiring rigorous time-consuming optimization processes for their incorporation in a suitable membrane environment. Currently available and widely used membrane mimetic systems are detergent micelles, bicelles, liposomes, lipodiscs, and lipodisq nanoparticles/SMALPs (styrene maleic acid lipid particles) [12-16]. These membrane mimetic systems have their own benefits and limitations.

Detergent micelles are commonly utilized to isolate and solubilize membrane proteins from cell membranes for their structural characterization using biophysical approaches. Due to the high curvature and varying lateral pressure profile of micelle systems, it is very challenging to verify whether the biophysical characterization data obtained for proteindetergent micelle systems represent the biologically relevant state. Bicelles are created by mixing long chain lipid and a short chain detergent to form artificial lipid bilayers. The requirement of specific types of lipid and detergent combination to form bicelles can restrict its application to several membrane proteins for biophysical studies.

Liposomes are aggregates of lipid molecules in aqueous solution forming a large spherical bilayer that can retain the native membrane environment for biophysical studies of membrane proteins. However, their larger size and heterogeneous sample nature make them difficult to study with certain biophysical approaches including solution NMR spectroscopy [9]. In addition, it is also challenging to concentrate proteins into liposomes leading to poor signal-to-noise in biophysical measurements [10]. The use of nanodisc as membrane mimetic systems has been very popular recently in biophysical studies of membrane protein with the benefit of no restriction on the types of lipids that can be used [17-19]. This system utilizes membrane scaffold protein as a solubilizing unit which may potentially affect the optical studies of the target protein. Recently, a new membrane mimetic system known as lipodisq nanoparticles or styrene maleic acid lipid nanoparticles (SMALPs) have been developed with a great potential as a better membrane mimetic system when compared to traditional membrane model systems [11,15,16,20-32]. Lipodisq nanoparticles are composed of 3:1 styrene maleic acid (SMA) copolymer and phospholipids. This is highly desirable because the structural and functional properties can be maintained which is not common for traditional membrane mimetics. Additionally, lipodisq nanoparticles are easy to prepare in detergent free environment and suitable for several biophysical approaches including NMR and EPR spectroscopic techniques. Figure 1 shows an illustrative example of the incorporation of membrane protein human voltage sensing domain of KCNQ1 (KCNQ1-VSD) (PDB ID: 6MIE) in detergent micelles and lipid bilayers.
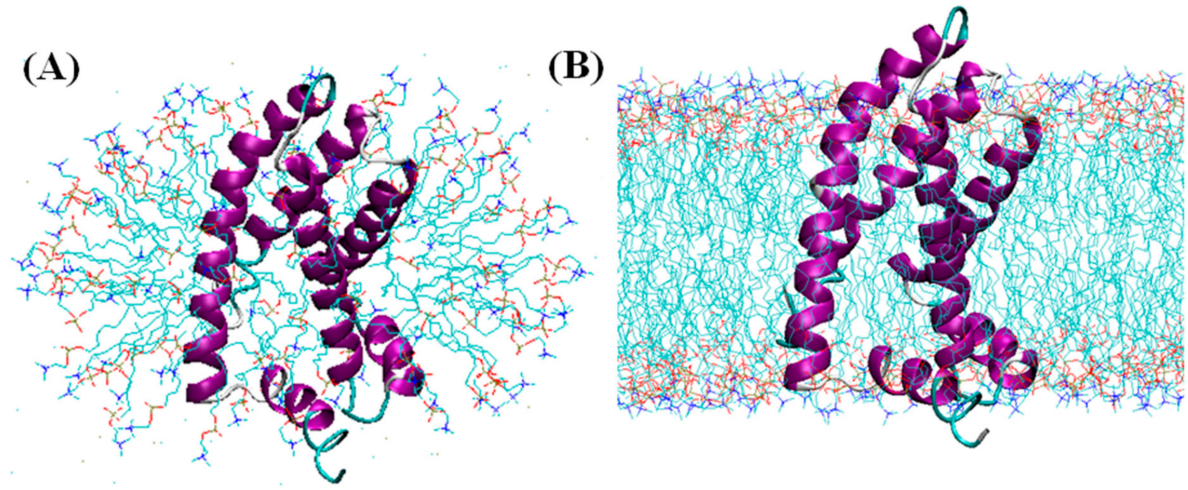

Figure 1. Cartoon representation of an example of the membrane protein human KCNQ1 voltage sensing domain (KCNQ1VSD) (PDB ID: 6MIE) incorporated into detergent micelles (Dodecylphosphocholine (DPC)) (A), and lipid bilayers (1,2Dimyristoyl-sn-glycero-3-phosphocholine (DMPC)) (B). Image was prepared using visual molecular dynamics (VMD) [33] and molecular modeling was performed using CHARMM-GUI (http:/ / www.charmm-gui.org, accessed on 18 December 2020) [34]. 


\section{Challenges and Recent Improvements Using Biophysical Techniques for Studying Membrane Proteins}

In recent years, great efforts have been made to develop technical and methodological improvements in structural biology approaches for studying membrane proteins. However, the challenges introduced in sample preparation of membrane proteins in suitable membrane environments and their complex behavior in lipid bilayer membrane environments severely limit the application of biophysical approaches for studying membrane proteins [35-41]. X-ray crystallography and nuclear magnetic resonance (NMR) spectroscopy are the two most successful and widely utilized biophysical techniques for obtaining structural data on protein systems. These biophysical techniques have their own pros and cons. X-ray crystallography provides very well resolved structural data, but limited by in-depth dynamic information [42]. Additionally, the hydrophobicity of membrane proteins also hinders the crystal formation process, causing difficulties for studying many membrane proteins by X-ray crystallographic techniques [43]. NMR spectroscopy can be also used to obtain data related to dynamic information for a numerous biological systems. Solution NMR spectroscopic methods can be used to probe the structural properties in membrane mimetic environments, however, this approach is limited by the size of the membrane protein (restricted to $<\sim 50 \mathrm{kD}$ ) [44-46]. In addition, the size of the micelle complex and the wider spectral linewidth, and spectral overlapping also introduce challenges in NMR structural studies of several membrane proteins [35,39]. These techniques require a large amount of highly pure and properly folded membrane protein samples to obtain high resolution structural data limiting their application for several membrane protein systems [47,48]. Other biophysical techniques like Förster resonance energy transfer (FRET) can be used to monitor the conformational changes of individual membrane protein systems. However, due to the requirement of relatively larger probe sizes, this technique may cause higher structural perturbation. Furthermore, the site-specific incorporation of the FRET probe throughout the sequence can be challenging [18]. Recently, cryogenic electron microscopy (Cryo-EM) has been developed as a powerful biophysical technique for probing threedimensional structures of biological systems at near-atomic resolutions due to technical improvements and instrumentation [49-52]. Cryo-EM requires much smaller amount of samples and doesn't need protein crystallization and hence, can be applied to a variety of membrane protein samples with a wide range of molecular weights that overcomes the challenges associated with X-ray crystallography and NMR spectroscopy [49]. Despite the great benefit of this technique, there are protein size restrictions $(<\sim 50 \mathrm{kDa})$ [53]. Electron paramagnetic resonance (EPR) spectroscopy has evolved as a highly growing powerful biophysical technique to resolve these challenges and provide prominent solutions to obtain structural and dynamic information on peptides, proteins, macromolecules, and nucleic acids [5,6,54-62].

\section{Site Directed Spin Labeling (SDSL) Approaches for EPR Spectroscopy}

EPR spectroscopy is a magnetic resonance technique that detects materials that contain an unpaired electron. In the presence of an external magnetic field, EPR measures interactions of microwave radiation with the energy splitting of the unpaired electron. EPR spectroscopy works on the principle similar to that of nuclear magnetic resonance (NMR) spectroscopy. The difference is that NMR detects the coupling of NMR-active nuclei of the individual atom with an external magnetic field opposed to the detection of the coupling of unpaired electron with an external magnetic field in the species by EPR. Due to the involvement of the unpaired electron in the spin probe, this technique is very sensitive and can provide up to three orders of magnitude higher sensitivity when compared to nuclear magnetic resonance (NMR) spectroscopic techniques [57]. EPR techniques are complementary to NMR for studying bio-macromolecules. In a continuous wave (CW)-EPR experiment, an external magnetic field is varied at a fixed electromagnetic radiation (microwave) frequency until the EPR transition occurs at the resonance condition when the constant microwave energy matches with the energy associated with the separation between the two electron 
spin states [63]. The magnetic field is additionally modulated to improve the signal to noise of the EPR signal leading to a derivative lineshape spectrum typically observed in most CW-EPR experiments. Details of theory behind CW- EPR spectroscopic methods can be found in the literature [63-65]. EPR spectroscopy can solve several biologically important problems that are very difficult to be studied by conventional biophysical techniques. These include structural and dynamic information for protein systems in solution and membrane bound states $[5,55,60,66]$.

Site-directed spin labeling (SDSL) is a molecular biology approach in which paramagnetic spin labels are incorporated into the specific site of bio-macromolecules. This technique was developed by Hubbell and co-workers more than three decades back [67-69]. In the early history, the lack of the unpaired electrons in most biological systems hindered the application of EPR techniques to limited bio-macromolecules such as metalloproteins containing paramagnetic centers and enzymes with radicals. The development of SDSL approaches helped quickly expand the application of EPR to almost any biological systems. In SDSL, all native nondisulfide-bonded cysteines are removed by switching them with another amino acid such as serine or an alanine. A unique cysteine residue is then incorporated into a recombinant protein using site-directed mutagenesis technique, followed by a reaction with sulfhydryl-specific nitroxide reagent to covalently generate a stable spin label side-chain $[59,70,71]$. Nitroxide spin labels have conformational flexibility with the label scaffold, and the linker between the scaffold and the backbone of the protein. The nitroxide spin labels are kinetically or sterically stabilized by carbon centers in the $\alpha$-position to the nitrogen atom with alkyl substituents (i.e., methyl, ethyl or higher alkyl substituents) against the reduction of nitroxides [72,73]. Detailed scheme of nitroxide spin labels with different alkyl substituents can be found in the recent literature [73-75]. However, larger spin labels still have an increased potential to perturb the structure of the labeled protein. It is critical to optimize the introduction of the nitroxide spin labels during the sample preparation to obtain a stable spin label side chain with minimal structural-functional perturbations on the protein of interest. The most commonly used nitroxide based spin label for studying structural dynamics of membrane proteins is methanethiosulfonate spin label (MTSL). Recently, a more restricted bifunctional spin label (BSL) has been utilized to perform EPR studies of membrane proteins and peptides [11,76-79]. A chemical structure of MTSL and BSL, and an illustrative example of the reaction of MTSL and BSL with the cysteine residues of the protein and resulting spin label side-chains are shown in Figure 2. Details of nitroxide spin labels utilized for site-directed spin labeling EPR study of bio-macromolecules can be found in the literature [72,80].

For typical SDSL experiments on membrane proteins, a 10-20 molar excess of MTSL is mixed with membrane protein samples containing cysteine residue at the site specific location solubilized in the appropriate buffer and $\mathrm{pH}$ containing detergent micelles [81]. The reaction is carried out at room temperature or $4{ }^{\circ} \mathrm{C}$ for overnight or $24 \mathrm{~h}$ depending on the stability of the protein. The non-bonded free spin labels are removed using standard dialysis, or passing through a PD-10 desalting column or size exclusion or ion chromatographic techniques. The spin labeling efficiency is usually determined by comparing protein concentration with the spin label concentration obtained from CW-EPR spectral intensity and analyzing mass spectroscopy data [82]. The optimum spin labeling efficiency is very important to achieve superior EPR data quality.

CW-EPR spectroscopy of spin-labeled macromolecules can provide structural dynamics of nitroxide side-chain, solvent accessibility, solvent polarity, and intra- or intermolecular distances between two nitroxides [5,6,41,59,72,83]. The EPR spectral lineshape analysis of the series of spin-labeled protein sequences can be used to probe the secondary structural information of the protein systems [41,84-87]. 
(A)<smiles>CC1(C)C=C(CSS(C)(=O)=O)C(C)(C)N1O</smiles>

MTSL<smiles>CC1(C)C(CSS(C)(=O)=O)=C(CSS(C)(=O)=O)C(C)(C)N1O</smiles>

BSL

(B)

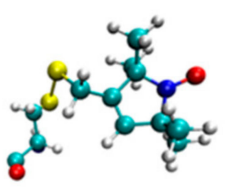

MTSL

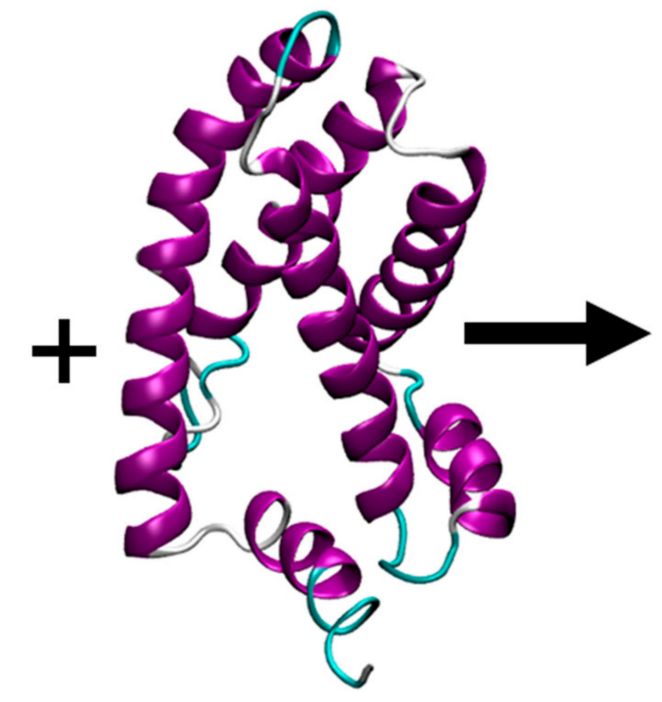

KCNQ1-VSD

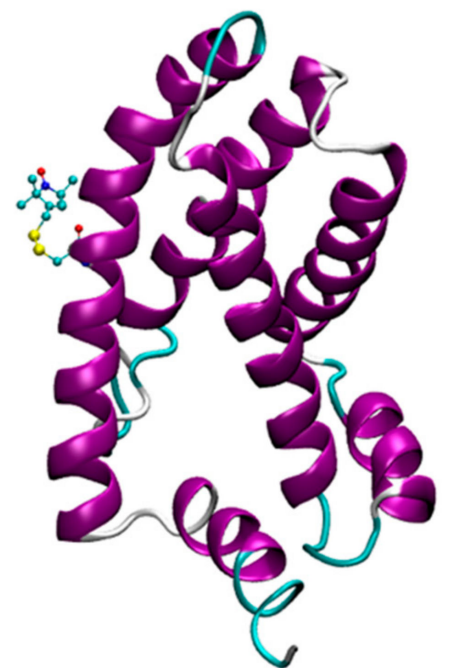

MTSL Labeled KCNQ1-VSD

(C)

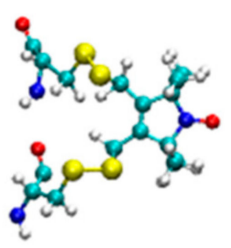

BSL

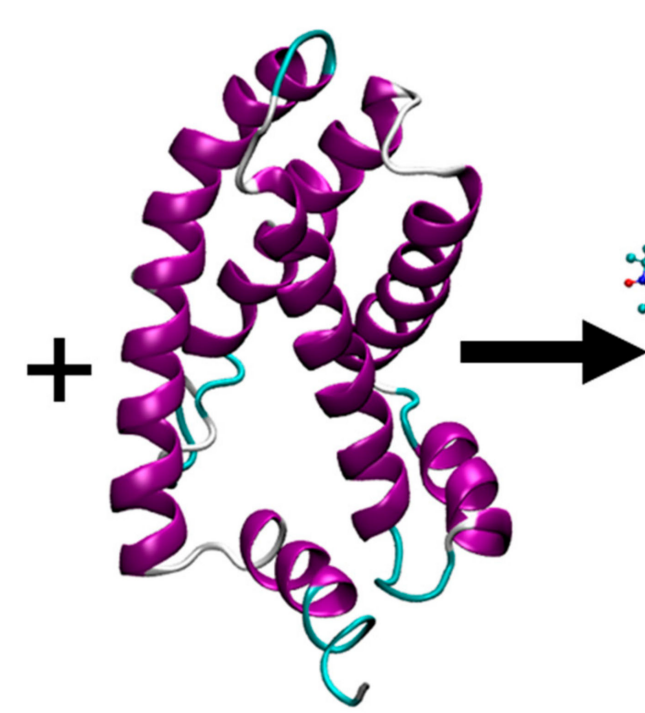

KCNQ1-VSD

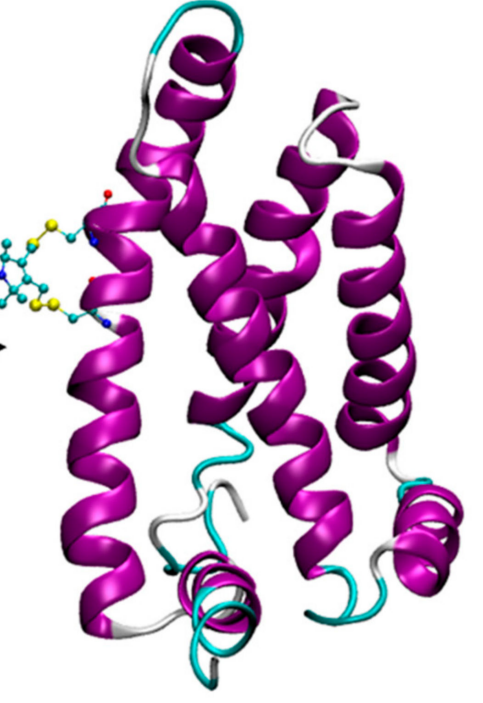

BSL Labeled KCNQ1-VSD

Figure 2. (A) A chemical structure of MTSL (methanethiosulfonate spin label) and BSL (bifunctional spin label). (B) Cartoon representation of the structure of MTSL and the resulting side-chain produced by reaction with a cysteine residue (L134C) and (C) the structure of BSL (bifunctional spin label) and the resulting side-chain produced by reaction with cysteine residues (L134C and I138C) on a KCNQ1-VSD membrane protein. The incorporation of MTSL and BSL spin labels on KCNQ1-VSD (PDB ID:6MIE) was obtained using Charmm-GUI (http:/ / www.charmm-gui.org, accessed on 6 March 2021) [34]. The cartoon structure of the MTSL-labeled and BSL-labeled KCNQ1-VSD was rendered using visual molecular dynamics (VMD) [33]. 
Distance measurements obtained by using double SDSL EPR spectroscopy is very popular and a rapidly growing structural biology technique to probe secondary, tertiary and quaternary structures of bio-macromolecules [41,72,88-90]. Distances and distance distribution can be also utilized to obtain conformational rearrangements or complex formation of membrane proteins. The relative orientations between interacting spin labels on the protein can be obtained by using dual SDSL EPR techniques [91,92]. The measurement of magnetic dipolar interactions between two spin labels is analyzed to determine distance between spin labels. The energy of the magnetic dipolar interaction is inversely related to the cube of the distance $\left(\mathrm{r}^{-3}\right)$ between two spin labels attached on the protein system. The magnetic dipolar interaction significantly broadens the CW-EPR spectral lineshape if the distance is less than $20 \AA$. The strength of the dipolar interaction is calculated qualitatively from the degree of line broadening using a variety of lineshape analysis techniques to obtain distance information [88,91,93-97].

A distance range of 20-80 $\mathrm{A}$ can be measured by using pulsed double electron electron resonance (DEER) spectroscopy [98]. For DEER experiments, the dipolar coupling between two spins can be measured by observing one set of spins when another set of spins are excited with a second microwave frequency. This leads to a determination of the distance between these two spin labels [98-100]. In DEER, intramolecular dipolar interaction modulates the spin echo decay of one set of spin labels with another set of spin labels on the same protein molecule and/or same set of spins or another set of spins on a separate molecule. The oscillating echo periodicity during the former process directly relates the average distance and distance distribution, while later process is an exponential decay which diminishes the oscillation, which is known as the background. The background contribution is removed from the echo decay during the data analysis providing distance distribution accounted by the weighted average distance and a standard deviation. There are several data analysis program freely available including the DeerAnalysis program developed by Jeschke et al. to obtain distance and related information from experimental DEER data [101]. Recently, DEERLab is a new program established for data analysis using Python [102]. A new method based on Deep neural network processing of DEER data has been developed by Worswick et al. and has been incorporated as options into Spinach and DeerAnalysis packages [103].

Nitroxide spin labeling based SDSL DEER spectroscopy is a widely used biophysical technique for studying secondary, tertiary and quaternary structures, and conformational dynamics of a numerous membrane proteins $[6,11,32,41,83,98,104-110]$. However, other spin labels including functionalized chelators of paramagnetic lanthanides $\left(\mathrm{Gd}^{\mathrm{III}}\right)$, carbonbased radicals ((trityl), and metals such as copper $\left(\mathrm{Cu}^{\mathrm{II}}\right)$ have been recently applied for DEER experiments for studying membrane proteins [111-116]. A special care should be taken while choosing specific spin labels and spin labeling sites on membrane proteins because some non-nitroxide spin labels are bulkier such as Gd-based and trityl labels than nitrixide spin labels which can cause perturbation in protein structure and function [111-114,117]. Earlier studies have suggested that there is no significant perturbation on the structure and/or function of the protein due to nitroxide spin labeling on membrane proteins [6,118-120]. However, spin labeling at particular sites of some of membrane proteins may cause significant structural and functional perturbation and poor expression yield, and hence a care should be taken during the experimental design of nitroxide spin labeling sites for double spin labeling experiments. Details of the theory and pulse sequences behind DEER measurements can be found in following excellent references $[41,99,107,121]$.

\section{Application of EPR Coupled with SDSL for Investigation of Membrane Proteins}

EPR spectroscopy coupled with SDSL has been extensively utilized to study membrane proteins. This is a very broad topic. In the following sections, we will discuss this topic in an introductory manner with emerging examples to answer pertinent structural dynamics 
related questions on membrane proteins. We refer the following excellent reviews for detail information $[5,6,41,61,66,72,90,122]$.

\subsection{Structural Topology and Dynamic Properties of Membrane Proteins}

EPR spectral lineshape is highly sensitive to the motion of the spin label side-chain of the protein. The dynamic properties of the nitroxide based spin labeled side-chain of protein molecules can be determined by analyzing the CW-EPR spectra [5]. The flexibility of the MTSL nitroxide spin label is also affected by the side-chain motion of the neighboring amino acid and secondary structure components in its immediate surroundings. The lineshape of the EPR spectrum represents the mobility of the spin label side-chain of the protein induced by its local structure and solvent environment. The CW-EPR spectrum lowers to three isotropic peaks for the rapidly moving spin labels in aqueous solution. When the spin label motion is very slow or motionless, the CW-EPR spectrum is known to be in the rigid limit regime [123]. In the case of a frozen sample in the rigid limit regime, the full orientation dependent EPR parameters can be observed. If the spin label sidechain motion of the protein lies in between isotropic and rigid limit regime, a rotational correlation time $\left(\tau_{\mathrm{c}}\right)$ can be determined from the EPR spectra [123]. The overall mobility of the protein containing nitroxide spin label side-chain is the superposition of contributions from the motion of spin labels relative to the protein backbone, fluctuations of the $\alpha$-carbon backbone, and the rotational motion of the entire protein. These motions can be isolated from the EPR spectrum by employing different experimental conditions. A relative mobility of the spin label side-chain can be determined by calculating the inverse central linewidth of the EPR spectrum $[5,78,81,83]$. The binding properties of the protein/peptide and membranes can be obtained by calculating the changes in the spin-label mobility [122,124]. The isotropic EPR spectrum of a spin-labeled peptide or small protein rapidly tumbling in a aqueous solvent has the rotational correlation time of approximately $<1 \mathrm{~ns}$. However, spin labeled peptides/proteins experience restricted motion in a lipid membrane system resulting a broader EPR spectrum with two motional components developed from the superposition of the signals arising from a free and bound peptides $[28,81,122,125,126]$. The more quantitative information about the spin label side-chain motion of membrane proteins can be determined by using spectral simulation methods such as Easyspin, and non-linear least squares (NLSL) $[58,66,67]$. EPR power saturation technique in association with site-directed spin labeling can be used to study the topology of the protein with respect to the lipid bilayer membrane $[6,28,126,127]$.

Structural dynamic properties and topology of several biologically important protein systems have been investigated using SDSL EPR spectroscopic techniques. Some of the important systems include Escherichia coli ferric citrate transporter FecA, GM2 activator protein, pentameric ligand-gated ion channels (pLGICs), ABC cassette transporter MsbA, cytochrome C oxidase subunit IV (COX IV), the prokaryotic potassium channel KcsA, KCNE1, KCNQ1-voltage sensing domain (VSD), lactose permease protein, integrin $\beta_{1 a}$, functional amyloid Obr2A, C99 domain of the amyloid precursor protein, bacteriorhodopsin, mechanosensitive channel of small conductance (MscS), KvAP voltage-sensing domain, phospholamban (PLB), and bacteriophase pinholin $S^{21}[78,81,87,119,124,126-141]$.

An illustrative example of using SDSL EPR spectroscopy is the study of the motion of pentameric ligand-gated ion channels (pLGICs) [142]. Pentameric ligand-gated ion channels (pLGICs) are neurotransmitter-activated receptors. They are involved in mediating fast synaptic transmission. pLGICs contain five identical/homologous subunits arranged pseudosymmetrically around a central ion-conducting channel. Ligand-gated ion channels are found in the membranes of nerve and muscle cells. These proteins form channels spanning the membrane, where they convert chemical signals into changes in electrical excitability. Dellisanti et al. obtained CW-EPR spectra on several MTSL spin labeled prototypical ligand-gated channel (GLIC) derivatives reconstituted into liposomes [142]. The CW-PER spectra were analyzed to determine the proton-induced changes in spin label mobility in the terms of inverse central linewidth to quantitatively report the ligand induced motion 
in regions at the boundary between the binding domain (loops 2 and 9) and the channel domain (M2-M3 loop) [142]. This study further applied the pulse EPR double electron electron resonance (DEER) technique to obtain distances between spin label probes in GLIC at different $\mathrm{pH}$ dependent conformational states. The DEER distance data suggested the structural rearrangements of the intra- and intersubunit interface between the extracellular binding domain (ECD) and transmembrane channel domain (TMD) accompany pLGIC gating transitions from closed to desensitized states.

A recent example of using SDSL CW-EPR spectroscopy is the study of the structural dynamics of the inactive form of pinholin $S^{21}$ [139]. Holins work as porters during the infected cell lysis process. They are regulated by different kinds of protein inhibitors. Holins co-expressed with an inhibitary holin known as antiholin. The precise timing of the biological/molecular clocks are characterized by their corresponding antiholin. Pinholin $S^{21}$ is encoded by the $S 21$ gene of phage $\Phi 21$. Antipinholin ( $S^{21} 68_{\text {IRS }}$ ) contains 71 amino acids with two putative transmembrane domains (TMDs) incorporated into the inner cytoplasmic membrane, making the $\mathrm{N}$ and $\mathrm{C}$-termini remaining in the cytoplasm. $S^{21} 68_{\text {IRS }}$ delays the formation of the active dimer which is a prerequisite for the pinhole formation $[143,144]$. Ahammad et al. extensively utilized CW-EPR spectra collected for spin-labeled antipinholin $S^{21} 68_{\text {IRS }}$ to investigate the structural dynamics of the inactive form of pinholin $S^{21} 68_{\text {IRS }}$ in 1,2-dimyristoyl-sn-glycero-3-phosphocholine (DMPC) lipid bilayers [139]. The CW-EPR spectral line shape analysis of the R1 side-chain for 35 residue positions of $S^{21} 68_{\text {IRS }}$ suggested that both transmembrane domains (TMDs) have more restricted mobility inside the lipid bilayers when compared to the $\mathrm{N}$ - and C-termini R1 side-chains. In addition, the R1 accessibility test performed on 24 residues using the CW-EPR power saturation experiment indicated that TMD1 and TMD2 of $S^{21} 68_{\text {IRS }}$ were incorporated into the lipid bilayers where $\mathrm{N}$ - and C-termini were located outside of the lipid bilayer. Based on this study, a tentative model of $S^{21} 68_{\text {IRS }}$ was proposed where both TMDs remain incorporated into the lipid bilayer and $\mathrm{N}$ - and C-termini are located outside of the lipid bilayer. Figure 3 shows the relative mobility of R1 side-chain $\left(\delta^{-1}\right)$ as a function of residue positions of the primary sequence of $S^{21} 68_{\text {IRS }}$, membrane depth parameter $(\Phi)$ as a function of $S^{21} 68_{\text {IRS }}$ residue positions in DMPC proteoliposomes at room temperature, and the proposed structural topology model of inactive pinholin $S^{21} 68_{\text {IRS }}$ incorporated into lipid bilayers. The depth parameter $(\phi)$ was determined by analyzing the power saturation data obtained under three equilibrium sample conditions: samples were equilibrated with (1) lipid soluble paramagnetic relaxant (21\% oxygen), (2) nitrogen gas as a control, and (3) water-soluble paramagnetic relaxant ( $2 \mathrm{mM}$ NiEDDA) with a continuous purge of nitrogen gas using the Equation (1) [139].

$$
\phi=\ln \left(\frac{\Delta P_{1 / 2}\left(O_{2}\right)}{\Delta P_{\frac{1}{2}}(N i E D D A)}\right)
$$

where, $\Delta P_{1 / 2}\left(O_{2}\right)$ is the difference in $P_{1 / 2}$ values of air and nitrogen eqilibrated samples, and $\Delta P_{1 / 2}(N i E D D A)$ is the difference in the $P_{1 / 2}$ values for NiEDDA and nitrogen equilibrated samples. The $P_{1 / 2}$ is the power at which the amplitude of the first derivative is decreased to half of its unsaturated value. 

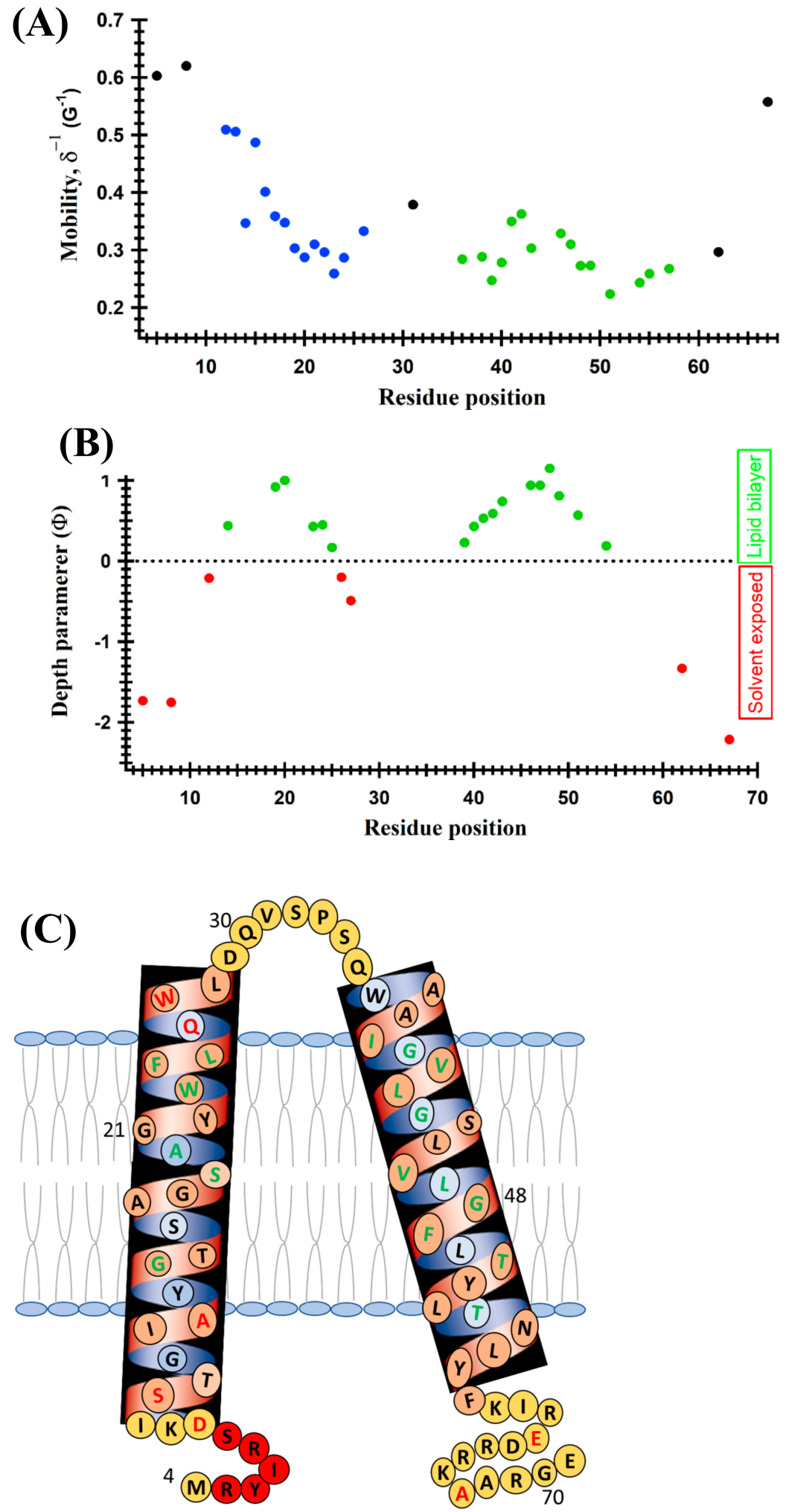

Figure 3. (A) The relative mobility of $\mathrm{R} 1\left(\delta^{-1}\right)$ as a function of residue positions of the primary sequence of $\mathrm{S}^{21} 68_{\text {IRS. }}$. Blue closed circles represent TMD1 residues, green for TMD2, and black indicating loop and terminal regions. (B) Membrane depth parameter $(\phi)$ as a function of the $S^{21} 68^{\mathrm{IRS}}$ residue positions in DMPC lipid-bilayered vesicles at room temperature. (C) The proposed structural topology model of the $S^{21} 68_{\text {IRS }}$ in DMPC lipid bilayers. (Adapted from [139] with permission). 
Another recent example of using SDSL EPR spectroscopic technique is the investigation of the conformational dynamics of the sensory Rhodopsin II in nanolipoprotein and styrene-maleic acid lipid particles [145]. The sensory Rhodopsin II of Natronomonas pharaonis (NpSRII) is a membrane-embedded photoreceptor that mediates the photorepellent response to potentially harmful blue light. This protein forms a transmembrane complex with its conjugate transducer, NpHtrII, of Natronomonas pharaonis and plays a key role in negative phototaxis. The structural-function relationship of NpSRII are linked to those of the light-driven proton pump bacteriorhodopsin (BR) [145]. Mosslehy et al. applied SDSL and time-resolved optical and CW-EPR spectroscopic techniques to compare the light-induced conformational dynamics of NpSRII, in the presence and absence of NpHtrII, reconstituted into three different lipid environments (SMALPs, NLPs and liposomes) [145]. Authors performed CW-EPR spectral lineshape analysis on the MTSL spin labeled site of NpSRII and its complex with NpHtrII that suggested a strong sterical interaction between the nitroxide and neighboring residues of the protein as expected for the spin label side-chain being buried between helices F and G. Similarly, the CW-EPR lineshape analysis on the MTSL spin labeled site of NpHtrII in the presence of NpSRII exhibited a composite spectral lineshape, showing the presence of at least two components related to mobile $(\mathrm{vm}, \mathrm{m})$ and immobile (i) fractions of the spin label side-chain. The spin label side-chain mobility data further indicated that the protein is less flexible in SMALPs. In addition, the transient CW-EPR light-dark difference spectra revealed light-dependent conformational changes in NpSRII and NpSRII/NpHtrII in liposomes, NLPs as well as in SMALPs. Authors further concluded that the SMALPs could be suitable for the preparation of stable and functional membrane protein samples for spectroscopic studies of their conformation and dynamics with possible restrictions of conformational changes in the transmembrane region of proteins [145].

\subsection{Distance Measurement on Membrane Proteins Using Dual SDSL EPR Spectroscopy}

$\mathrm{CW}$ dipolar broadening EPR method is used to obtain an intermediate distance range of 8-20 A that can provide pertinent structural and dynamic information of the protein system [146]. Recently, a high-frequency $(94 \mathrm{GHz})$ electron-nuclear double resonance (ENDOR) method using ${ }^{19} \mathrm{~F}$ nuclei and nitroxide spin labels has been applied to obtain distance measurements up to $\sim 15 \AA$ with an accuracy of $0.1-1 \AA$ [147]. There are several important biological systems that have been studied using SDSL CW-EPR dipolar broadening techniques. Some significant examples include: bacteriorhodopsin, sensory rhodopsin II (NpSRII)/transducer NpHtrII from natronobacterium pharaonis, erythroid $\beta$ spectrin, AchR M2 $\delta$ peptide, magainin 2 peptide, WALP peptide, bacterial $\mathrm{K}^{+}$-translocating protein KtrB, E. coli integral membrane sulfurtransferase (YgaP), and KCNE1 [76,92,96,148-156].

Accurate and precise distance measurements are difficult for membrane proteins due to difficulties in integral membrane protein sample preparation in their physiological environment. A shorter phase memory/transverse relaxation times and lower DEER modulations are observed for membrane proteins in more native like vesicle samples when compared to water soluble proteins or membrane proteins in detergent micelles [43,144]. The heterogeneous distribution of spin-labeled protein within the membrane causes local inhomogeneous pockets of high spin concentration leading to the shorter phase memory time. The proton spin diffusion arising due to the presence of hydrogen atoms in the acyl chains of the lipid in addition to those in the solvent and in the protein cause further decrease in the phase memory time $[157,158]$. The requirement of a high effective protein concentration in the liposome samples introduces strong background contributions leading to decrease in the sensitivity, distance range, and experimental throughput [159]. Additionally, the backbone dynamics of the protein and the rotameric motion of spin-labels also contribute to the width of the DEER distance distribution. Technical and methodological developments have been recently enhanced in the structural biology field to minimize these limitations to obtain superior DEER data quality for membrane proteins. The reconstitution of membrane proteins has been optimized in the presence of 
unlabeled proteins, bicelles, nanodics, lipodisq nanoparticles, low protein/lipid molar ratio and restricted spin label probes [11,32,41,160-167]. Using deuterated protein and solvents can also enhance the phase memory times that contribute towards the improvement of signal/noise and the data quality [111]. DEER measurements are also carried out at Q-band to increase sensitivity $[11,32,160,165]$. The use of an arbitrary waveform generator (AWG) to EPR has further improved data quality in DEER pulsed EPR experiments [121]. DEER distance restraints in association with the computational methods of molecular dynamics simulations have also been widely used to refine the structural properties of membrane proteins [32,78,110,168-170].

Nitroxide based SDSL DEER spectroscopy has been applied to study several membrane protein systems including KvAP voltage-sensing domain, pentameric ligand-gated channel, E. coli integral membrane sulfurtransferase (YgaP), bacteriorhodopsin, KCNE1, KCNE3, C99 amyloid precursor protein, human dihydroorotate dehydrogenase enzyme $(\mathrm{HsDHODH})$, influenza A M2 protein, outer membrane cobalamin transporter BtuB in intact E. coli, cardiac $\mathrm{Na}^{+} / \mathrm{Ca}^{2+}$ exchange (NCX1.1) protein, $\mathrm{Na}^{+} /$Proline transporter PutP Escherichia coli, tetrameric potassium ion channel KcsA, $\alpha$-synuclein, membranefusion $\mathrm{K} / \mathrm{E}$ peptides, ABC transporter MsbA, HCN channels, YetJ membrane protein, ectodomain of gp41, multimeric membrane transport proteins, and multidrug transporter LmrP [32,78,150,161-163,167-186].

A recent example of using nitroxide based SDSL DEER spectroscopy is the study of the conformational changes of the active and inactive forms of Pinholin $S^{21}$ [110]. Pinholin S21 is a class-II holin, encoded by the S21 gene of phage $\Phi 21$. It encodes two holin proteins, pinholin $S^{21} 68$ (lysis effector) and antipinholin $S^{21} 68_{\text {IRS }}$ (lysis inhibitor). The antipinholin form differs from pinholin only by three extra amino acids at the N-terminus. Ahmmad et al. applied the four pulse DEER technique to measure distances between transmembrane domains 1 and 2 (TMD1 and TMD2) to investigate the structural topology and conformations of active pinholin $\left(S^{21} 68\right)$ and inactive antipinholin $\left(S^{21} 68_{\text {IRS }}\right)$ in DMPC $(1,2-$ dimyristoyl-snglycero-3-phosphocholine) proteoliposomes [110]. The researchers utilized five sets of interlabel DEER distances obtained for both the active and inactive forms of pinholin $S^{21}$ as experimental DEER distance restraints coupled with the simulated annealing software package Xplor-NIH to predict structural models of the active pinholin and inactive antipinholin. Figure 4 shows representative SDSL-based DEER data on active pinholin and overlay of the ribbon representation of the eight structures with the lowest energy obtained from restrained simulated annealing calculations using the amino acids of active pinholin and inactive pinholin in DMPC liposomes. The results of DEER experiments and predicted structural models suggested that the TMD2 of $S^{21} 68$ remains in the lipid bilayer, and TMD1 is partially externalized from the bilayer with some residues located on the surface. However, both TMDs remain incorporated in the lipid bilayer for the inactive $S^{21} 68_{\text {IRS }}$ form. This study was consistent with earlier CW-EPR spectral lineshape analysis and power saturation data obtained on pinholin $S^{21}[139,140]$.

Another recent example of the application of nitroxide based DEER spectroscopy is the study of the Human KCNQ1 voltage sensing domain (Q1-VSD) in lipodisq nanoparticles [14]. Human KCNQ1 is a voltage-gated potassium channel modulated by members of the KCNE protein family. Q1-VSD is a four-transmembrane protein consisting of 149 amino acids representing the first four helices (S1-S4) of KCNQ1. Sahu et al. performed four pulsed Q-band DEER experiments on Q1-VSD mutants (F123C-S143C) incorporated into various membrane mimetics including DPC micelles, LMPG micelles, DMPC/DPC bicelles, POPC/POPG lipid bilayers, and POPC/POPG lipodisq nanoparticles for distance measurements [14]. These distances on Q1-VSD were closely matching for each membrane environment within the experimental error suggesting that the secondary structural conformation of Q1-VSD is closely matching in all of these membrane environments. The DEER data further suggested a substantial improvement in the signal-to-noise ratio $(\mathrm{S} / \mathrm{N})$ for DEER time domain data with the phase memory time increased by $\sim 2$-fold for lipodisq nanoparticle samples when compared to the same spin-labeled Q1-VSD pro- 
tein in POPC/POPG lipid bilayers. In addition, the CW-EPR spectral lineshape analysis performed on three individual positions (F130C and V165C on the TMDs and Q147C on the outside of the membrane) on Q1-VSD at different temperatures from $297 \mathrm{~K}$ to $325 \mathrm{~K}$ suggested an increase in spectral line broadening for the spin labeled Q1-VSD mutations in lipodisq nanoparticles when compared to that in liposomes.
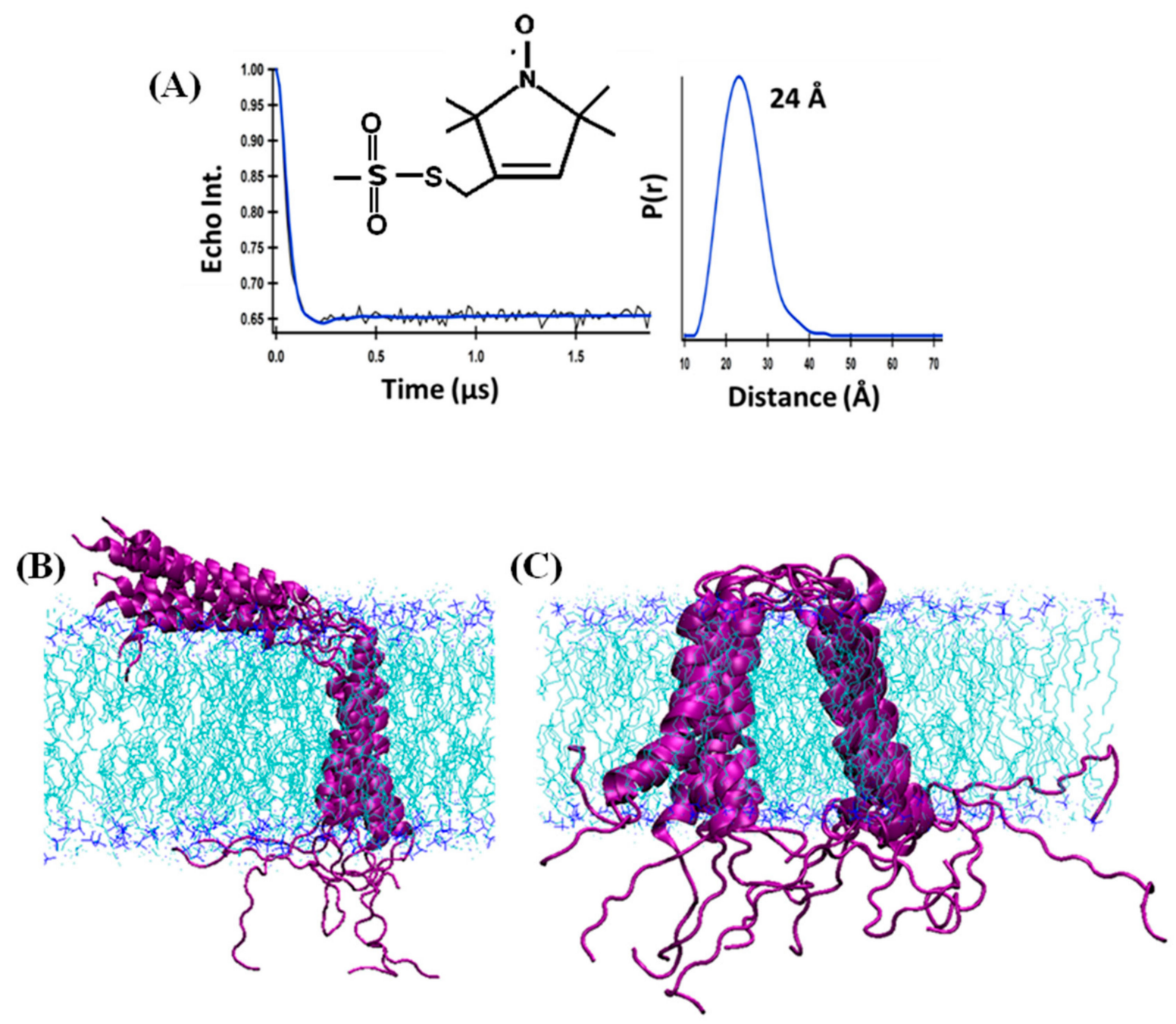

Figure 4. An illustrative example of four pulse Q-band DEER data on active form of pinholin (S $\left.{ }^{21} 68\right)$ mutants (W27-A38) bearing two MTSL spin labels (A). The left panel shows time domain DEER data and right panel shows probability distance distribution data. The schematic representation of the MTSL spin labeling probe is shown as inset in the left panel of the figure. Overlay of the ribbon representation of the eight lowest energy structures of active form of pinholin ( $\left.S^{21} 68\right)(\mathbf{B})$, and inactive form of pinholin ( ${ }^{21} 68_{\text {IRS }}$ ) (C) in DMPC lipid bilayers. (Adapted from [110] with permission).

SDSL based DEER spectroscopy has been recently applied to investigate conformations of the extracellular loops of BtuB in whole cells $[187,188]$. BtuB is an outer membrane $(\mathrm{OM})$ protein of E. Coli TonB-dependent Cobalamin (vitamin $B_{12}$ ) transporter [187]. The extracellular loops of BtuB show gating motions and conformational samplings during substrate transport [187]. Nyenhuis et al. utilized site-directed spin labeling DEER spectroscopic distance data collected between eight double spin labeling extracellular loop sites in a native in situ environment to verify whether the loops are conformationally heterogeneous and undergo a significant gating movement upon the addition of substrate [187]. Their DEER distance distribution measurements indicated that the loops are more ordered in an in situ environment, and substrate binding produces very minor or no changes in loop structure [187]. This study also showed an absence of large gating motions in the 
native system in contrary to that in liposomes in response to substrate. This study further suggested that the conformation of the extracellular loops of outer membrane proteins measured in vitro may not necessarily represent those in the vivo environment suggesting that membrane reconstitutions of outer membrane proteins may not incorporate all the elements required to reproduce the native protein structure.

\section{Conclusions}

In this review, we briefly described some of the most popular SDSL based EPR spectroscopic techniques and their emerging applications to investigate structural dynamics of important biological systems. SDSL based EPR spectroscopic techniques are rapidly growing biophysical tools applied to glean structural dynamics information of biological systems. Recent technological and methodological improvements on EPR spectroscopy have expanded its application to more complicated biological systems which is very difficult or nearly impossible by using other existing biophysical techniques.

Funding: This research received no external funding.

Data Availability Statement: Not Applicable.

Acknowledgments: This work was generously supported by an NIGMS/NIH Maximizing Investigator's Research Award (MIRA) R35 GM126935 award and an NSF CHE-1807131 grant to G.A.L. G.A.L. would also like to acknowledge support from the John W. Steube Professorship. I.D.S. would like to acknowledge support from an NSF MCB-2040917 award.

Conflicts of Interest: The authors declare no conflict of interest.

\section{References}

1. Congreve, M.; Marshall, F. The impact of GPCR structures on pharmacology and structure-based drug design. Br. J. Pharmacol. 2010, 159, 986-996. [CrossRef] [PubMed]

2. Baker, M. Structural biology: The gatekeepers revealed. Nature 2010, 465, 823-826. [CrossRef] [PubMed]

3. Chou, K.C.; Elrod, D.W. Prediction of membrane protein types and subcellular locations. Proteins Struct. Funct. Genet. 1999, 34, 137-153. [CrossRef]

4. Engel, A.; Gaub, H.E. Structure and Mechanics of Membrane Proteins. Annu. Rev. Biochem. 2008, 77, 127-148. [CrossRef] [PubMed]

5. Klug, C.S.; Feix, J.B. Methods and Applications of Site-Directed Spin Labeling EPR Spectroscopy. Methods Cell Biol. 2008, 84, 617-658. [PubMed]

6. Sahu, I.D.; McCarrick, R.M.; Lorigan, G.A. Use of Electron Paramagnetic Resonance to Solve Biochemical Problems. Biochemistry 2013, 52, 5967-5984. [CrossRef] [PubMed]

7. Das, B.B.; Park, S.H.; Opella, S.J. Membrane protein structure from rotational diffusion. Biochim. Biophys. Acta 2015, 1848, 229-245. [CrossRef]

8. Kang, H.J.; Lee, C.; Drew, D. Breaking the barriers in membrane protein crystallography. Int. J. Biochem. Cell Biol. 2013, 45, 636-644. [CrossRef] [PubMed]

9. Hemminga, M.A.; Berliner, L.J. ESR Spectroscopy in Membrane Biophysics; Springer: New York, NY, USA, 2007.

10. Carpenter, E.P.; Beis, K.; Cameron, A.D.; Iwata, S. Overcoming the challenges of membrane protein crystallography. Curr. Opin. Struct. Biol. 2008, 18, 581-586. [CrossRef]

11. Sahu, I.D.; McCarrick, R.M.; Troxel, K.R.; Zhang, R.; Smith, H.J.; Dunagan, M.M.; Swartz, M.S.; Rajan, P.V.; Kroncke, B.M.; Sanders, C.R.; et al. DEER EPR Measurements for Membrane Protein Structures via Bifunctional Spin Labels and Lipodisq Nanoparticles. Biochemistry 2013, 52, 6627-6632. [CrossRef]

12. Harding, B.D.; Dixit, G.; Burridge, K.M.; Sahu, I.D.; Dabney-Smith, C.; Edelmann, R.E.; Konkolewicz, D.; Lorigan, G.A. Characterizing the structure of styrene-maleic acid copolymer-lipid nanoparticles (SMALPs) using RAFT polymerization for membrane protein spectroscopic studies. Chem. Phys. Lipids 2019, 218, 65-72. [CrossRef]

13. Burridge, K.M.; Harding, B.D.; Sahu, I.D.; Kearns, M.M.; Stowe, R.B.; Dolan, M.T.; Edelmann, R.E.; Dabney-Smith, C.; Page, R.C.; Konkolewicz, D.; et al. Simple Derivatization of RAFT-Synthesized Styrene-Maleic Anhydride Copolymers for Lipid Disk Formulations. Biomacromolecules 2020, 21, 1274-1284. [CrossRef]

14. Sahu, I.D.; Dixit, G.; Reynolds, W.D.; Kaplevatsky, R.; Harding, B.D.; Jaycox, C.K.; McCarrick, R.M.; Lorigan, G.A. Characterization of the Human KCNQ1 Voltage Sensing Domain (VSD) in Lipodisq Nanoparticles for Electron Paramagnetic Resonance (EPR) Spectroscopic Studies of Membrane Proteins. J. Phys. Chem. B 2020, 124, 2331-2342. [CrossRef] [PubMed] 
15. Craig, A.F.; Clark, E.E.; Sahu, I.D.; Zhang, R.; Frantz, N.D.; Al-Abdul-Wahid, M.S.; Dabney-Smith, C.; Konkolewicz, D.; Lorigan, G.A. Tuning the size of styrene-maleic acid copolymer-lipid nanoparticles (SMALPs) using RAFT polymerization for biophysical studies. Biochim. Biophys. Acta 2016, 1858, 2931-2939. [CrossRef] [PubMed]

16. Orwick-Rydmark, M.; Lovett, J.E.; Graziadei, A.; Lindholm, L.; Hicks, M.R.; Watts, A. Detergent-Free Incorporation of a Sev-enTransmembrane Receptor Protein into Nanosized Bilayer Lipodisq Particles for Functional and Biophysical Studies. Nano Lett. 2012, 12, 4687-4692. [CrossRef]

17. Bayburt, T.H.; Sligar, S.G. Membrane protein assembly into Nanodiscs. FEBS Lett. 2010, 584, 1721-1727. [CrossRef] [PubMed]

18. Bayburt, T.H.; Sligar, S.G. Self-assembly of single integral membrane proteins into soluble nanoscale phospholipid bilayers. Protein Sci. 2003, 12, 2476-2481. [CrossRef] [PubMed]

19. Denisov, I.G.; Grinkova, Y.V.; Lazarides, A.A.; Sligar, S.G. Directed self-assembly of monodisperse phospholipid bilayer nano-discs with controlled size. J. Am. Chem. Soc. 2004, 126, 3477-3487. [CrossRef] [PubMed]

20. Orwick, M.C.; Judge, P.J.; Procek, J.; Lindholm, L.; Graziadei, A.; Engel, A.; Gröbner, G.; Watts, A. Detergent-Free Formation and Physicochemical Characterization of Nanosized Lipid-Polymer Complexes: Lipodisq. Angew. Chem. Int. Ed. 2012, 51, $4653-4657$. [CrossRef]

21. Jamshad, M.; Lin, Y.-P.; Knowles, T.J.; Parslow, R.A.; Harris, C.; Wheatley, M.; Poyner, D.R.; Bill, R.M.; Thomas, O.R.; Overduin, M.; et al. Surfactant-free purification of membrane proteins with intact native membrane environment. Biochem. Soc. Trans. 2011, 39, 813-818. [CrossRef]

22. Knowles, T.J.; Finka, R.; Smith, C.; Lin, Y.-P.; Dafforn, T.; Overduin, M. Membrane Proteins Solubilized Intact in Lipid Containing Nanoparticles Bounded by Styrene Maleic Acid Copolymer. J. Am. Chem. Soc. 2009, 131, 7484-7485. [CrossRef]

23. Rajesh, S.; Knowles, T.; Overduin, M. Production of membrane proteins without cells or detergents. New Biotechnol. 2011, 28, 250-254. [CrossRef] [PubMed]

24. Long, A.R.; O’Brien, C.C.; Malhotra, K.; Schwall, C.T.; Albert, A.D.; Watts, A.; Alder, N.N. A detergent-free strategy for the re-constitution of active enzyme complexes from native biological membranes into nanoscale discs. BMC Biotechnol. 2013, 13, 41. [CrossRef]

25. Jamshad, M.; Grimard, V.; Idini, I.; Knowles, T.J.; Dowle, M.R.; Schofield, N.; Sridhar, P.; Lin, Y.; Finka, R.; Wheatley, M.; et al. Structural analysis of a nano-particle containing a lipid bilayer used for detergent-free extraction of membrane proteins. Nano Res. 2015, 8, 774-789. [CrossRef]

26. Lund, A.; Andersson, P.; Eriksson, J.; Hallin, J.; Johansson, T.; Jonsson, R.; Lofgren, H.; Paulin, C.; Tell, A. Automatic fitting pro-cedures for EPR spectra of disordered systems: Matrix diagonalization and perturbation methods applied to fluorocarbon radicals. Spectrochim. Acta Part A 2008, 69, 1294-1300. [CrossRef]

27. Zhang, R.; Sahu, I.D.; Liu, L.; Osatuke, A.; Comer, R.G.; Dabney-Smith, C.; Lorigan, G.A. Characterizing the structure of lipodisq nanoparticles for membrane protein spectroscopic studies. Biochim. Biophys. Acta Biomembr. 2015, 1848, 329-333. [CrossRef] [PubMed]

28. Kim, S.S.; Upshur, M.A.; Saotome, K.; Sahu, I.D.; McCarrick, R.M.; Feix, J.B.; Lorigan, G.A.; Howard, K.P. Cholesterol-Dependent Conformational Exchange of the C-Terminal Domain of the Influenza A M2 Protein. Biochemistry 2015, 54, 7157-7167. [CrossRef]

29. Scheidelaar, S.; Koorengevel, M.C.; Pardo, J.D.; Meeldijk, J.D.; Breukink, E.; Killian, J.A. Molecular Model for the Solubilization of Membranes into Nanodisks by Styrene Maleic Acid Copolymers. Biophys. J. 2015, 108, 279-290. [CrossRef]

30. Dörr, J.M.; Scheidelaar, S.; Koorengevel, M.C.; Dominguez, J.J.; Schäfer, M.; Van Walree, C.A.; Killian, J.A. The styrene-maleic acid copolymer: A versatile tool in membrane research. Eur. Biophys. J. EBJ 2016, 45, 3-21. [CrossRef]

31. Dörr, J.M.; Koorengevel, M.C.; Schäfer, M.; Prokofyev, A.V.; Scheidelaar, S.; Van Der Cruijsen, E.A.W.; Dafforn, T.R.; Baldus, M.; Killian, J.A. Detergent-free isolation, characterization, and functional reconstitution of a tetrameric K+channel: The power of native nanodiscs. Proc. Natl. Acad. Sci. USA 2014, 111, 18607-18612. [CrossRef] [PubMed]

32. Sahu, I.D.; Kroncke, B.M.; Zhang, R.; Dunagan, M.M.; Smith, H.J.; Craig, A.; McCarrick, R.M.; Sanders, C.R.; Lorigan, G.A. Structural Investigation of the Transmembrane Domain of KCNE1 in Proteoliposomes. Biochemistry 2014, 53, 6392-6401. [CrossRef] [PubMed]

33. Humphrey, W.; Dalke, A.; Schulten, K. VMD-Visual Molecular Dynamics. J. Mol. Graph. 1996, 14, 33-38. [CrossRef]

34. Jo, S.; Kim, T.; Iyer, V.G.; Im, W. Software news and updates-CHARNIM-GUI: A web-based graphical user interface for CHARMM. J. Comput. Chem. 2008, 29, 1859-1865. [CrossRef]

35. Liang, B.; Tamm, L.K. NMR as a Tool to Investigate Membrane Protein Structure, Dynamics and Function. Nat. Struct. Mol. Biol. 2016, 23, 468-474. [CrossRef] [PubMed]

36. Bordag, N.; Keller, S. $\alpha$-Helical transmembrane peptides: A “Divide and Conquer" approach to membrane proteins. Chem. Phys. Lipids 2010, 163, 1-26. [CrossRef] [PubMed]

37. Moraes, L.G.; Fázio, M.A.; Vieira, R.F.; Nakaie, C.R.; Miranda, M.T.M.; Schreier, S.; Daffre, S.; Miranda, A. Conformational and functional studies of gomesin analogues by CD, EPR and fluorescence spectroscopies. Biochim. Biophys. Acta Biomembr. 2007, 1768, 52-58. [CrossRef]

38. Baker, M. Making membrane proteins for structures: A trillion tiny tweaks. Nat. Methods 2010, 7, 429-434. [CrossRef] [PubMed]

39. Torres, J.; Stevens, T.J.; Samso, M. Membrane proteins: The 'Wild West' of structural biology. Trends Biochem. Sci. 2003, 28, 137-144. [CrossRef] 
40. Huang, C.; Mohanty, S. Challenging the Limit: NMR Assignment of a 31 kDa Helical Membrane Protein. J. Am. Chem. Soc. 2010, 132, 3662-3663. [CrossRef]

41. Sahu, I.D.; Lorigan, G.A. Electron Paramagnetic Resonance as a Tool for Studying Membrane Proteins. Biomolecules 2020, 10, 763. [CrossRef]

42. Columbus, L.; Hubbell, W.L. A new spin on protein dynamics. Trends Biochem. Sci. 2002, 27, 288-295. [CrossRef]

43. Acharya, K.R.; Lloyd, M.D. The advantages and limitations of protein crystal structures. Trends Pharmacol. Sci. 2005, 26, 10-14. [CrossRef] [PubMed]

44. Wüthrich, K. NMR studies of structure and function of biological macromolecules (Nobel Lecture). J. Biomol. NMR 2003, 27, 13-39. [CrossRef] [PubMed]

45. Schiemann, O.; Prisner, T.F. Long-range distance determinations in biomacromolecules by EPR spectroscopy. Q. Rev. Biophys. 2007, 40, 1-53. [CrossRef]

46. Lecoq, L.; Fogeron, M.-L.; Meier, B.H.; Nassal, M.; Böckmann, A. Solid-State NMR for Studying the Structure and Dynamics of Viral Assemblies. Viruses 2020, 12, 1069. [CrossRef] [PubMed]

47. Midgett, C.R.; Madden, D.R. Breaking the bottleneck: Eukaryotic membrane protein expression for high-resolution structural studies. J. Struct. Biol. 2007, 160, 265-274. [CrossRef]

48. Bahar, I.; Lezon, T.R.; Bakan, A.; Shrivastava, I.H. Normal Mode Analysis of Biomolecular Structures: Functional Mechanisms of Membrane Proteins. Chem. Rev. 2010, 110, 1463-1497. [CrossRef]

49. Callaway, E. The protein-imaging technique taking over structural biology. Nature 2020, 578, 201. [CrossRef]

50. Autzen, H.E.; Julius, D.; Cheng, Y.F. Membrane mimetic systems in CryoEM: Keeping membrane proteins in their native envi-ronment. Curr. Opin. Struct. Biol. 2019, 58, 259-268. [CrossRef]

51. Nakane, T.; Kotecha, A.; Sente, A.; McMullan, G.; Masiulis, S.; Brown, P.M.G.E.; Grigoras, I.T.; Malinauskaite, L.; Malinauskas, T.; Miehling, J.; et al. Single-particle cryo-EM at atomic resolution. Nature 2020, 587, 152-156. [CrossRef]

52. Yip, K.M.; Fischer, N.; Paknia, E.; Chari, A.; Stark, H. Atomic-resolution protein structure determination by cryo-EM. Nature 2020, 587, 157-161. [CrossRef] [PubMed]

53. Liu, Y.X.; Huynh, D.T.; Yeates, T.O. A 3.8 angstrom resolution cryo-EM structure of a small protein bound to an imaging scaffold. Nat. Commun. 2019, 10, 1-7.

54. Fanucci, G.E.; Cafiso, D.S. Recent advances and applications of site-directed spin labeling. Curr. Opin. Struct. Biol. 2006, 16, 644-653. [CrossRef] [PubMed]

55. Hubbell, W.L.; Gross, A.; Langen, R.; Lietzow, M.A. Recent advances in site-directed spin labeling of proteins. Curr. Opin. Struct. Biol. 1998, 8, 649-656. [CrossRef]

56. Qin, P.Z.; Dieckmann, T. Application of NMR and EPR methods to the study of RNA. Curr. Opin. Struct. Biol. 2004, 14, 350-359. [CrossRef] [PubMed]

57. Berliner, L.J. From spin-labeled proteins to in vivo EPR applications. Eur. Biophys. J. 2010, 39, 579-588. [CrossRef]

58. Speicher, D.W. Characterization of protein primary structure. Dev. Biol. Stand. 1998, 96, 27-28.

59. Klare, J.P.; Steinhoff, H.-J. Spin labeling EPR. Photosynth. Res. 2009, 102, 377-390. [CrossRef]

60. Hubbell, W.L.; Mchaourab, H.S.; Altenbach, C.; Lietzow, M.A. Watching proteins move using site-directed spin labeling. Structure 1996, 4, 779-783. [CrossRef]

61. Hubbell, W.L.; López, C.J.; Altenbach, C.; Yang, Z. Technological advances in site-directed spin labeling of proteins. Curr. Opin. Struct. Biol. 2013, 23, 725-733. [CrossRef]

62. Claxton, D.P.; Kazmier, K.; Mishra, S.; McHaourab, H.S. Navigating Membrane Protein Structure, Dynamics, and Energy Landscapes Using Spin Labeling and EPR Spectroscopy. Methods Enzymol. 2015, 564, 349-387.

63. Weil, J.A.; Bolton, J.R. Electron Paramagnetic Resonance: Elementary Theory and Practical Applications; Wiley-Interscience: Hoboken, NJ, USA, 2007.

64. Goldfarb, D.; Stoll, S. EPR Spectroscopy: Fundamentals and Methods; John Wiley and Sons Ltd.: Hoboken, NJ, USA, 2018.

65. Roessler, M.M.; Salvadori, E. Principles and applications of EPR spectroscopy in the chemical sciences. Chem. Soc. Rev. 2018, 47, 2534-2553. [CrossRef] [PubMed]

66. Bordignon, E.; Steinhoff, H.-J. Membrane Protein Structure and Dynamics Studied by Site-Directed Spin-Labeling ESR. In ESR Spectroscopy in Membrane Biophysics; Springer: Boston, MA, USA, 2007; Volume 27, pp. 129-164.

67. Altenbach, C.; Flitsch, S.L.; Khorana, H.G.; Hubbell, W.L. Structural studies on transmembrane proteins. 2. Spin labeling of bacteriorhodopsin mutants at unique cysteines. Biochemistry 1989, 28, 7806-7812. [CrossRef] [PubMed]

68. Altenbach, C.; Froncisz, W.; Hyde, J.; Hubbell, W. Conformation of spin-labeled melittin at membrane surfaces investigated by pulse saturation recovery and continuous wave power saturation electron paramagnetic resonance. Biophys. J. 1989, 56, $1183-1191$. [CrossRef]

69. Altenbach, C.; Marti, T.; Khorana, H.G.; Hubbell, W.L. Transmembrane protein structure: Spin labeling of bacteriorhodopsin mutants. Science 1990, 248, 1088-1092. [CrossRef] [PubMed]

70. Steinhoff, H.-J. Multi-Frequency EPR Spectroscopy Studies of the Structure and Conformational Changes of Site-Directed Spin Labelled Membrane Proteins. In Supramolecular Structure and Function 8; Springer: Boston, MA, USA, 2005; Volume 8, pp. 157-177.

71. Cornish, V.W.; Benson, D.R.; Altenbach, C.A.; Hideg, K.; Hubbell, W.L.; Schultz, P.G. Site-specific incorporation of biophysical probes into proteins. Proc. Natl. Acad. Sci. USA 1994, 91, 2910-2914. [CrossRef] 
72. Roser, P.; Schmidt, M.J.; Drescher, M.; Summerer, D. Site-directed spin labeling of proteins for distance measurements in vitro and in cells. Org. Biomol. Chem. 2016, 14, 5468-5476. [CrossRef]

73. Haugland, M.M.; Lovett, J.E.; Anderson, E.A. Advances in the synthesis of nitroxide radicals for use in biomolecule spin labelling. Chem. Soc. Rev. 2018, 47, 668-680. [CrossRef]

74. Karthikeyan, G.; Bonucci, A.; Casano, G.; Gerbaud, G.; Abel, S.; Thomé, V.; Kodjabachian, L.; Magalon, A.; Guigliarelli, B.; Belle, V.; et al. A Bioresistant Nitroxide Spin Label for In-Cell EPR Spectroscopy: In Vitro and In Oocytes Protein Structural Dynamics Studies. Angew. Chem. Int. Ed. 2018, 57, 1366-1370. [CrossRef] [PubMed]

75. Bleicken, S.; Assafa, T.E.; Zhang, H.; Elsner, C.; Ritsch, I.; Pink, M.; Rajca, S.; Jeschke, G.; Rajca, A. Bordignon, E. gem-Diethyl Pyrroline Nitroxide Spin Labels: Synthesis, EPR Characterization, Rotamer Libraries and Biocompatibility. Chemistryopen 2019, 8, 1057-1065. [CrossRef]

76. Sahu, I.D.; Craig, A.F.; Dunagum, M.M.; McCarrick, R.M.; Lorigan, G.A. Characterization of bifunctional spin labels for investigating the structural and dynamic properties of membrane proteins using EPR spectroscopy. J. Phys. Chem. B 2017, 121, 9185-9195. [CrossRef]

77. McCaffrey, J.E.; James, Z.M.; Svensson, B.; Binder, B.P.; Thomas, D.D. A bifunctional spin label reports the structural topology of phospholamban in magnetically-aligned bicelles. J. Magn. Reson. 2016, 262, 50-56. [CrossRef] [PubMed]

78. Li, Q.; Wanderling, S.; Sompornpisut, P.; Perozo, E.; Somponspisut, P. Structural basis of lipid-driven conformational transitions in the KvAP voltage-sensing domain. Nat. Struct. Mol. Biol. 2014, 21, 160-166. [CrossRef]

79. Lösel, R.M.; Philipp, R.; Kálai, T.; Hideg, K.; Trommer, W.E. Synthesis and Application of Novel Bifunctional Spin Labels. Bioconjug. Chem. 1999, 10, 578-582. [CrossRef] [PubMed]

80. Haugland, M.M.; Anderson, E.A.; Lovett, J.E. Tuning the properties of nitroxide spin labels for use in electron paramagnetic resonance spectroscopy through chemical modification of the nitroxide framework. In Electron Paramagnetic Resonance; Chechik, V., Murphy, D.M., Eds.; Royal Society of Chemistry (RSC): London, UK, 2017; pp. 1-34.

81. Sahu, I.D.; Craig, A.F.; Dunagan, M.M.; Troxel, K.R.; Zhang, R.; Meiberg, A.G.; Harmon, C.N.; McCarrick, R.M.; Kroncke, B.M.; Sanders, C.R.; et al. Probing Structural Dynamics and Topology of the KCNE1 Membrane Protein in Lipid Bilayers via Site-Directed Spin Labeling and Electron Paramagnetic Resonance Spectroscopy. Biochemistry 2015, 54, 6402-6412. [CrossRef]

82. Basak, S.; Chatterjee, S.; Chakrapani, S. Site directed spin labeling and EPR spectroscopic studies of pntameric ligand-gated ion channels. JOVE J. Vis. Exp. 2016, 113, 54127.

83. Sahu, I.D.; Lorigan, G.A. Biophysical EPR Studies Applied to Membrane Proteins. J. Phys. Chem. Biophys. 2015, 5, 188. [CrossRef]

84. Jeschke, G.; Bender, A.; Schweikardt, T.; Panek, G.; Decker, H.; Paulsen, H. Localization of the N-terminal Domain in Lightharvesting Chlorophyll a/b Protein by EPR Measurements. J. Biol. Chem. 2005, 280, 18623-18630. [CrossRef]

85. Mchaourab, H.S.; Perozo, E. Determination of Protein Folds and Conformational Dynamics Using Spin-Labeling EPR Spectroscopy. In Biological Magnetic Resonance; Berliner, L., Eaton, G., Eaton, S., Eds.; Springer: New York, NY, USA, 2002; pp. 185-247.

86. Perozo, E.; Cortes, D.M.; Cuello, L.G. Three-dimensional architecture and gating mechanism of a K+ channel studied by EPR spectroscopy. Nat. Struct. Biol. 1998, 5, 459-469. [CrossRef]

87. Vasquez, V.; Sotomayor, M.; Cortes, D.M.; Roux, B.; Schulten, K.; Perozo, E. Three-dimensional architecture of membraneembedded MscS in the closed conformation. J. Mol. Biol. 2008, 378, 55-70. [CrossRef]

88. Hustedt, E.J.; Beth, A.H. Nitroxide spin-spin interactions: Applications to protein structure and dynamics. Annu. Rev. Biophys. Biomol. Struct. 1999, 28, 129-153. [CrossRef]

89. Brown, L.J.; Hare, J.E. Electron Paramagnetic Resonance: Site-Directed Spin Labeling; John Wiley \& Sons, Inc.: Hoboken, NJ, USA, 2015.

90. Wunnicke, D.; Hänelt, I. The Synergetic Effects of Combining Structural Biology and EPR Spectroscopy on Membrane Proteins. Crystals 2017, 7, 117. [CrossRef]

91. Hustedt, E.; Smirnov, A.; Laub, C.; Cobb, C.; Beth, A. Molecular distances from dipolar coupled spin-labels: The global analysis of multifrequency continuous wave electron paramagnetic resonance data. Biophys. J. 1997, 72, 1861-1877. [CrossRef]

92. Ghimire, H.; Hustedt, E.J.; Sahu, I.D.; Inbaraj, J.J.; McCarrick, R.; Mayo, D.J.; Benedikt, M.R.; Lee, R.T.; Grosser, S.M.; Lorigan,

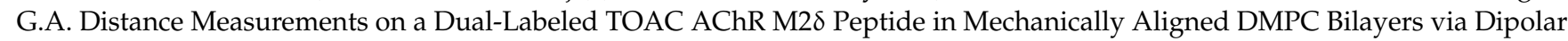
Broadening CW-EPR Spectroscopy. J. Phys. Chem. B 2012, 116, 3866-3873. [CrossRef] [PubMed]

93. Hustedt, E.J.; Stein, R.A.; Sethaphong, L.; Brandon, S.; Zhou, Z.; DeSensi, S.C. Dipolar Coupling between Nitroxide Spin Labels: The Development and Application of a Tether-in-a-Cone Model. Biophys. J. 2006, 90, 340-356. [CrossRef]

94. Banham, J.E.; Baker, C.M.; Ceola, S.; Day, I.J.; Grant, G.H.; Groenen, E.J.; Rodgers, C.T.; Jeschke, G.; Timmel, C.R. Distance measurements in the borderline region of applicability of CW EPR and DEER: A model study on a homologous series of spin-labelled peptides. J. Magn. Reson. 2008, 191, 202-218. [CrossRef] [PubMed]

95. Rabenstein, M.D.; Shin, Y.K. Determination of the distance between two spin labels attached to a macromolecule. Proc. Natl. Acad. Sci. USA 1995, 92, 8239-8243. [CrossRef] [PubMed]

96. Czogalla, A.; Pieciul, A.; Jezierski, A.; Sikorski, A.F. Attaching a spin to a protein—Site-directed spin labeling in structural biology. Acta Biochim. Pol. 2007, 54, 235-244. [CrossRef] [PubMed] 
97. Mandal, T.; Hustedt, E.J.; Song, L.; Oh, K.J. CW EPR and DEER Methods to Determine BCL-2 Family Protein Structure and Interactions: Application of Site-Directed Spin Labeling to BAK Apoptotic Pores. In BCL-2 Family Proteins; Methods in Molecular Biology; Gavathiotis, E., Ed.; Humana Press: New York, NY, USA, 2019; Volume 1877, pp. 257-303.

98. Jeschke, G.; Polyhach, Y. Distance measurements on spin-labelled biomacromolecules by pulsed electron paramagnetic resonance. Phys. Chem. Chem. Phys. 2007, 9, 1895-1910. [CrossRef]

99. Schweiger, A.; Jeschke, G. Principles of Pulse Electron Paramagnetic Resonance; Oxford University Press: New York, NY, USA, 2001.

100. Pannier, M.; Veit, S.; Godt, A.; Jeschke, G.; Spiess, H.W. Dead-time free measurement of dipole-dipole interactions between electron spins. J. Magn. Reson. 2000, 142, 331-340. [CrossRef]

101. Jeschke, G.; Chechik, V.; Ionita, P.; Godt, A.; Zimmermann, H.; Banham, J.; Timmel, C.R.; Hilger, D.; Jung, H. Deer Analysis 2006-A comprehensive software package for analyzing pulsed ELDOR data. Appl. Magn. Reson. 2006, 30, 473-498. [CrossRef]

102. Ibáñez, L.F.; Jeschke, G.; Stoll, S. DeerLab: A comprehensive software package for analyzing dipolar electron paramagnetic resonance spectroscopy data. Magn. Reson. 2020, 1, 209-224. [CrossRef]

103. Worswick, S.G.; Spencer, J.A.; Jeschke, G.; Kuprov, I. Deep neural network processing of DEER data. Sci. Adv. 2018, 4, eaat5218. [CrossRef] [PubMed]

104. Sahu, I.D.; Lorigan, G.A. Site-Directed Spin Labeling EPR for Studying Membrane Proteins. BioMed Res. Int. 2018, $2018,3248289$. [CrossRef]

105. Sahu, I.D.; Lorigan, G.A. EPR Techniques, Spin Labeling and Spin Trapping. In Encyclopedia of Analytical Science; Elsevier Ltd.: Amsterdam, The Netherlands, 2019; pp. 315-327.

106. Borbat, P.P.; McHaourab, H.S.; Freed, J.H. Protein structure determination using long-distance constraints from double-quantum coherence ESR: Study of T4 lysozyme. J. Am. Chem. Soc. 2002, 124, 5304-5314. [CrossRef]

107. Jeschke, G. DEER Distance Measurements on Proteins. Annu. Rev. Phys. Chem. 2012, 63, 419-446. [CrossRef] [PubMed]

108. Milov, A.D.; Tsvetkov, Y.D.; Formaggio, F.; Crisma, M.; Toniolo, C.; Raap, J. Self-assembling properties of membrane-modifying peptides studied by PELDOR and CW-ESR spectroscopies. J. Am. Chem. Soc. 2000, 122, 3843-3848. [CrossRef]

109. Hilger, D.; Jung, H.; Padan, E.; Wegener, C.; Vogel, K.P.; Steinhoff, H.J.; Jeschke, G. Assessing oligomerization of membrane proteins by four-pulse DEER: pH-dependent dimerization of NhaA Na+/H+ antiporter of E. coli. Biophys. J. 2005, 89, 1328-1338. [CrossRef]

110. Ahammad, T.A.; Drew, D.L.; Sahu, I.D.; Khan, R.H.; Butcher, B.J.; Serafin, R.A.; Galende, A.P.; McCarrick, R.M.; Lorigan, G.A. Conformational Differences are Observed for the Active and Inactive Forms of Pinholin $\mathrm{S}^{21}$ using DEER Spectroscopy. Phys. Chem. B 2020, 124, 11396-11405. [CrossRef]

111. Bordignon, E.; Bleicken, S. New limits of sensitivity of site-directed spin labeling electron paramagnetic resonance for membrane proteins. Biochim. Biophys. Acta Biomembr. 2018, 1860, 841-853. [CrossRef]

112. Feintuch, A.; Otting, G.; Goldfarb, D. Gd3+ Spin Labeling for Measuring Distances in Biomacromolecules: Why and How? In Methods in Enzymology; Electron Paramagnetic Resonance Investigations of Biological Systems by Using Spin Labels, Spin Probes, and Intrinsic Metal Ions, Part A; Elsevier: Amsterdam, The Netherlands, 2015; Volume 563, pp. 415-457.

113. Jassoy, J.J.; Berndhäuser, A.; Duthie, F.; Kühn, S.P.; Hagelueken, G.; Schiemann, O. Versatile Trityl Spin Labels for Nanometer Distance Measurements on Biomolecules In Vitro and within Cells. Angew. Chem. Int. Ed. 2017, 56, 177-181. [CrossRef]

114. Yang, Z.Y.; Ji, M.; Cunningham, T.F.; Saxena, S. Cu2+ as an ESR Probe of Protein Structure and Function. In Methods in Enzymology; Electron Paramagnetic Resonance Investigations of Biological Systems by Using Spin Labels, Spin Probes, and Intrinsic Metal Ions, Part A; Elsevier: Amsterdam, The Netherlands, 2015; Volume 563, pp. 459-481.

115. Joseph, B.; Sikora, A.; Cafiso, D.S. Ligand Induced Conformational Changes of a Membrane Transporter in E. coli Cells Observed with DEER/PELDOR. J. Am. Chem. Soc. 2016, 138, 1844-1847. [CrossRef]

116. Yardeni, E.H.; Bahrenberg, T.; Stein, R.A.; Mishra, S.; Zomot, E.; Graham, B.; Tuck, K.L.; Huber, T.; Bibi, E.; McHaourab, H.S.; et al. Probing the solution structure of the E. coli multidrug transporter MdfA using DEER distance measurements with nitroxide and Gd(III) spin labels. Sci. Rep. 2019, 9, 12528. [CrossRef]

117. Joseph, B.; Tormyshev, V.M.; Rogozhnikova, O.Y.; Akhmetzyanov, D.; Bagryanskaya, E.G.; Prisner, T.F. Selective High-Resolution Detection of Membrane Protein-Ligand Interaction in Native Membranes Using Trityl-Nitroxide PELDOR. Angew. Chem. Int. Ed. 2016, 55, 11538-11542. [CrossRef]

118. Altenbach, C.; Yang, K.; Farrens, D.L.; Farahbakhsh, Z.T.; Khorana, H.G.; Hubbell, W.L. Structural features and light-dependent changes in the cytoplasmic interhelical E-F loop region of rhodopsin: A site-directed spin-labeling study. Biochemistry 1996, 35, 12470-12478. [CrossRef] [PubMed]

119. Hubbell, W.L.; Altenbach, C. Investigation of structure and dynamics in membrane proteins using site-directed spin labeling. Curr. Opin. Struct. Biol. 1994, 4, 566-573. [CrossRef]

120. Fajer, P.G. Site directed spin labelling and pulsed dipolar electron paramagnetic resoonance (double electron-electron resonance) of force activation in muscle. J. Phys. Condens. Matter 2005, 17, S1459-S1469. [CrossRef]

121. Tait, C.E.; Stoll, S. Coherent pump pulses in Double Electron Electron Resonance spectroscopy. Phys. Chem. Chem. Phys. 2016, 18, 18470-18485. [CrossRef]

122. Klug, C.S.; Feix, J.B. SDSL: A survey of biological applications. Biol. Magn. Reson. 2004, 24, 269-308.

123. Stoll, S.; Schweiger, A. Easyspin: Simulating cw ESR spectra. Biol. Magn. Reson. 2007, 27, $299-321$. 
124. Soria, M.A.; Cervantes, S.A.; Bajakian, T.H.; Siemer, A.B. The Functional Amyloid Orb2A Binds to Lipid Membranes. Biophys. J. 2017, 113, 37-47. [CrossRef]

125. Victor, K.G.; Cafiso, D.S. Location and Dynamics of Basic Peptides at the Membrane Interface: Electron Paramagnetic Resonance Spectroscopy of Tetramethyl-Piperidine-N-Oxyl-4-Amino-4-Carboxylic Acid-Labeled Peptides. Biophys. J. 2001, 81, 2241-2250. [CrossRef]

126. Yu, L.; Wang, W.; Ling, S.; Liu, S.; Xiao, L.; Xin, Y.; Lai, C.; Xiong, Y.; Zhang, L.; Tian, C. CW-EPR studies revealed different motional properties and oligomeric states of the integrin beta(1a) transmembrane domain in detergent micelles or liposomes. Sci. Rep. 2015, 5, 7848. [CrossRef] [PubMed]

127. Altenbach, C.; Greenhalgh, D.A.; Khorana, H.G.; Hubbell, W.L. A collision gradient method to determine the immersion depth of nitroxides in lipid bilayers: Application to spin-labeled mutants of bacteriorhodopsin. Proc. Natl. Acad. Sci. USA 1994, 91, 1667-1671. [CrossRef]

128. Cortes, D.M.; Cuello, L.G.; Perozo, E. Molecular architecture of full-length KcsA-Role of cytoplasmic domains in ion permeation and activation gating. J. Gen. Physiol. 2001, 117, 165-180. [CrossRef] [PubMed]

129. Voss, J.; He, M.M.; Hubbell, W.L.; Kaback, H.R. Site-directed spin labeling demonstrates that transmembrane domain XII in the lactose permease of Escherichia coli is an alpha-helix. Biochemistry 1996, 35, 12915-12918. [CrossRef]

130. Song, Y.; Hustedt, E.J.; Brandon, S.; Sanders, C.R. Competition Between Homodimerization and Cholesterol Binding to the C99 Domain of the Amyloid Precursor Protein. Biochemistry 2013, 52, 5051-5064. [CrossRef]

131. Perozo, E.; Hubbell, W.L. Transmembrane voltage control in liposomes- the use of bacteriorhodopsin as a light-driven current source. Biophys. J. 1993, 64, A222.

132. Mokdad, A.; Herrick, D.Z.; Kahn, A.K.; Andrews, E.; Kim, M.; Cafiso, D.S. Ligand-Induced Structural Changes in the Escherichia coli Ferric Citrate Transporter Reveal Modes for Regulating Protein-Protein Interactions. J. Mol. Biol. 2012, 423, 818-830. [CrossRef]

133. Aziz, A.; Hess, J.F.; Budamagunta, M.S.; Voss, J.C.; FitzGerald, P.G. Site-directed Spin Labeling and Electron Paramagnetic Resonance Determination of Vimentin Head Domain Structure. J. Biol. Chem. 2010, 285, 15278-15285. [CrossRef]

134. Dong, J.; Yang, G.; Mchaourab, H.S. Structural Basis of Energy Transduction in the Transport Cycle of MsbA. Science 2005, 308, 1023-1028. [CrossRef]

135. Malmberg, N.J.; Falke, J.J. Use of EPR power saturation toanalyze the membrane-docking geometries of peripheral proteins: A applications to C2 domains. Annu. Rev. Biophys. Biomol. Struct. 2005, 34, 71-90. [CrossRef] [PubMed]

136. Yu, Y.G.; Thorgeirsson, T.E.; Shin, Y.-K. Topology of an Amphiphilic Mitochondrial Signal Sequence in the Membrane-Inserted State: A Spin Labeling Study. Biochemistry 1994, 33, 14221-14226. [CrossRef] [PubMed]

137. Klug, C.S.; Su, W.Y.; Feix, J.B. Mapping of the residues involved in a proposed beta-strand located in the ferric enterobactin receptor FepA using site-directed spin-labeling. Biochemistry 1997, 36, 13027-13033. [CrossRef]

138. Carter, J.D.; Mathias, J.D.; Gomez, E.F.; Ran, Y.; Xu, F.; Galiano, L.; Tran, N.Q.; D’Amore, P.W.; Wright, C.S.; Chakravorty, D.K.; et al. Characterizing Solution Surface Loop Conformational Flexibility of the GM2 Activator Protein. J. Phys. Chem. B 2014, 118, 10607-10617. [CrossRef]

139. Ahammad, T.; Drew, D.L.; Khan, R.H.; Sahu, I.D.; Faul, E.; Li, T.; Lorigan, G.A. Structural Dynamics and Topology of the Inactive Form of S21 Holin in a Lipid Bilayer Using Continuous-Wave Electron Paramagnetic Resonance Spectroscopy. J. Phys. Chem. B 2020, 124, 5370-5379. [CrossRef]

140. Ahammad, T.; Drew, D.L., Jr.; Sahu, I.D.; Serafin, R.A.; Clowes, K.R.; Lorigan, G.A. Continuous Wave Electron Paramagnetic Resonance Spectroscopy Reveals the Structural Topology and Dynamic Properties of Active Pinholin S2168 in a Lipid Bilayer. J. Phys. Chem. B 2019, 123, 8048-8056. [CrossRef] [PubMed]

141. Dixit, G.; Sahu, I.D.; Reynolds, W.D.; Wadsworth, T.M.; Harding, B.D.; Jaycox, C.K.; Dabney-Smith, C.; Sanders, C.R.; Lorigan, G.A. Probing the Dynamics and Structural Topology of the Reconstituted Human KCNQ1 Voltage Sensor Domain (Q1-VSD) in Lipid Bilayers Using Electron Paramagnetic Resonance Spectroscopy. Biochemistry 2019, 58, 965-973. [CrossRef]

142. Dellisanti, C.D.; Ghosh, B.; Hanson, S.M.; Raspanti, J.M.; Grant, V.A.; Diarra, G.M.; Schuh, A.M.; Satyshur, K.A.; Klug, C.S.; Czajkowski, C. Site-Directed Spin Labeling Reveals Pentameric Ligand-Gated Ion Channel Gating Motions. PLoS Biol. 2013, 11, e1001714. [CrossRef]

143. Pang, T.; Savva, C.G.; Fleming, K.G.; Struck, D.K.; Young, R. Structure of the lethal phage pinhole. Proc. Natl. Acad. Sci. USA 2009, 106, 18966-18971. [CrossRef] [PubMed]

144. Pang, T.; Park, T.; Young, R. Mutational analysis of the S21pinholin. Mol. Microbiol. 2010, 76, 68-77. [CrossRef]

145. Mosslehy, W.; Voskoboynikova, N.; Colbasevici, A.; Ricke, A.; Klose, D.; Klare, J.P.; Mulkidjanian, A.Y.; Steinhoff, H.J. Conformational Dynamics of Sensory Rhodopsin II in Nanolipoprotein and Styrene-Maleic Acid Lipid Particles. Photochem. Photobiol. 2019, 95, 1195-1204. [CrossRef] [PubMed]

146. Chiang, Y.-W.; Zheng, T.-Y.; Kao, C.-J.; Horng, J.-C. Determination of Interspin Distance Distributions by cw-ESR Is a Single Linear Inverse Problem. Biophys. J. 2009, 97, 930-936. [CrossRef]

147. Meyer, A.; Dechert, S.; Dey, S.; Höbartner, C.; Bennati, M. Measurement of Angstrom to Nanometer Molecular Distances with 19 F Nuclear Spins by EPR/ENDOR Spectroscopy. Angew. Chem. Int. Ed. 2020, 59, 373-379. [CrossRef] [PubMed]

148. Czogalla, A.; Jaszewski, A.R.; Diakowski, W.; Bok, E.; Jezierski, A.; Sikorski, A.F. Structural insight into an ankyrin-sensitive lipid-binding site of erythroid beta-spectrin. Mol. Membr. Biol. 2007, 24, 215-224. [CrossRef] 
149. Essen, L.O.; Siegert, R.; Lehmann, W.D.; Oesterhelt, D. Lipid patches in membrane protein oligomers: Crystal structure of the bacteriorhodopsin-lipid complex. Proc. Natl. Acad. Sci. USA 1998, 95, 11673-11678. [CrossRef] [PubMed]

150. Ling, S.; Wang, W.; Yu, L.; Peng, J.; Cai, X.; Xiong, Y.; Hayati, Z.; Zhang, L.; Zhang, Z.; Song, L.; et al. Structure of an E. coli integral membrane sulfurtransferase and its structural transition upon SCN- binding defined by EPR-based hybrid method. Sci. Rep. 2016, 6, 20025. [CrossRef]

151. Sahu, I.D.; Hustedt, E.J.; Ghimire, H.; Inbaraj, J.J.; McCarrick, R.M.; Lorigan, G.A. CW dipolar broadening EPR spectroscopy and mechanically aligned bilayers used to measure distance and relative orientation between two TOAC spin labels on an antimicrobial peptide. J. Magn. Reson. 2014, 249, 72-79. [CrossRef]

152. Hanelt, I.; Wunnicke, D.; Muller-Trimbusch, M.; Vor der Bruggen, M.; Kraus, I.; Bakker, E.P.; Steinhoff, H.J. Membrane Region $\mathrm{M}_{2 \mathrm{C} 2}$ in Subunit KtrB of the $\mathrm{K}^{+}$Uptake System KtrAB from Vibrio alginolyticus Forms a Flexible Gate Controlling $\mathrm{K}^{+}$Flux-An electron paramagnetic resonance study. J. Biol. Chem. 2010, 285, 28210-28219. [CrossRef]

153. Steinhoff, H.-J. Inter- and intra-molecular distances determined by EPR spectroscopy and site-directed spin labeling reveal protein-protein and protein-oligonucleotide interaction. Biol. Chem. 2004, 385, 913-920. [CrossRef]

154. Wegener, A.-A.; Klare, J.P.; Engelhard, M.; Steinhoff, H.-J. Structural insights into the early steps of receptor-transducer signal transfer in archaeal phototaxis. EMBO J. 2001, 20, 5312-5319. [CrossRef]

155. Scarpelli, F.; Drescher, M.; Rutters-Meijneke, T.; Holt, A.; Rijkers, D.T.S.; Killian, J.A.; Huber, M. Aggregation of Transmembrane Peptides Studied by Spin-Label EPR. J. Phys. Chem. B 2009, 113, 12257-12264. [CrossRef]

156. Yu, L.; Wang, W.; Ling, S.; He, Y.; Xiao, L.; Wu, K.; Zhang, L.; Tian, C. Distance measurement between two flexible sites in proteins in high viscosity medium at physiological temperature using continuous wave EPR. Protein Cell 2014, 5, 334-337. [CrossRef]

157. El Mkami, H.; Ward, R.; Bowman, A.; Owen-Hughes, T.; Norman, D.G. The spatial effect of protein deuteration on nitroxide spin-label relaxation: Implications for EPR distance measurement. J. Magn. Reson. 2014, 248, 36-41. [CrossRef]

158. Schmidt, T.; Walti, M.A.; Baber, J.L.; Hustedt, E.J.; Clore, G.M. Long Distance Measurements up to 160 angstrom in the GroEL Tetradecamer Using Q-Band DEER EPR Spectroscopy. Angew. Chem. Int. Ed. 2016, 55, 15905-15909. [CrossRef]

159. Mchaourab, H.S.; Steed, P.R.; Kazmier, K. Toward the Fourth Dimension of Membrane Protein Structure: Insight into Dynamics from Spin-Labeling EPR Spectroscopy. Structure 2011, 19, 1549-1561. [CrossRef] [PubMed]

160. Zou, P.; Mchaourab, H.S. Increased Sensitivity and Extended Range of Distance Measurements in Spin-Labeled Membrane Proteins: Q-Band Double Electron-Electron Resonance and Nanoscale Bilayers. Biophys. J. 2010, 98, L18-L20. [CrossRef] [PubMed]

161. Zou, P.; Bortolus, M.; Mchaourab, H.S. Conformational Cycle of the ABC Transporter MsbA in Liposomes: Detailed Analysis Using Double Electron-Electron Resonance Spectroscopy. J. Mol. Biol. 2009, 393, 586-597. [CrossRef]

162. Endeward, B.; Butterwick, J.A.; MacKinnon, R.; Prisner, T.F. Pulsed Electron-Electron Double-Resonance Determination of Spin-Label Distances and Orientations on the Tetrameric Potassium Ion Channel KcsA. J. Am. Chem. Soc. 2009, 131, 15246-15250. [CrossRef] [PubMed]

163. Georgieva, E.R.; Ramlall, T.F.; Borbat, P.P.; Freed, J.H.; Eliezer, D. Membrane-Bound $\alpha$-Synuclein Forms an Extended Helix: Long-Distance Pulsed ESR Measurements Using Vesicles, Bicelles, and Rodlike Micelles. J. Am. Chem. Soc. 2008, 130, 12856-12857. [CrossRef] [PubMed]

164. Xu, Q.; Ellena, J.F.; Kim, A.M.; Cafiso, D.S. Substrate-Dependent Unfolding of the Energy Coupling Motif of a Membrane Transport Protein Determined by Double Electron-Electron Resonance. Biochemistry 2006, 45, 10847-10854. [CrossRef]

165. Polyhach, Y.; Bordignon, E.; Tschaggelar, R.; Gandra, S.; Godt, A.; Jeschke, G. High sensitivity and versatility of the DEER experiment on nitroxide radical pairs at Q-band frequencies. Phys. Chem. Chem. Phys. 2012, 14, 10762-10773. [CrossRef]

166. Cunningham, T.F.; Putterman, M.R.; Desai, A.; Horne, W.S.; Saxena, S. The Double-Histidine Cu2+-Binding Motif: A Highly Rigid, Site-Specific Spin Probe for Electron Spin Resonance Distance Measurements. Angew. Chem. Int. Ed. 2015, 54, 6330-6334 [CrossRef]

167. Li, C.-C.; Hung, C.-L.; Yeh, P.-S.; Li, C.-E.; Chiang, Y.-W. Doubly spin-labeled nanodiscs to improve structural determination of membrane proteins by ESR. RSC Adv. 2019, 9, 9014-9021. [CrossRef]

168. Jao, C.C.; Hegde, B.G.; Chen, J.; Haworth, I.S.; Langen, R. Structure of membrane-bound alpha-synuclein from site-directed spin labeling and computational refinement. Proc. Natl. Acad. Sci. USA 2008, 105, 19666-19671. [CrossRef]

169. Milikisiyants, S.; Wang, S.; Munro, R.A.; Donohue, M.; Ward, M.E.; Bolton, D.; Brown, L.S.; Smirnova, T.I.; Ladizhansky, V.; Smirnov, A.I. Oligomeric Structure of Anabaena Sensory Rhodopsin in a Lipid Bilayer Environment by Combining Solid-State NMR and Long-range DEER Constraints. J. Mol. Biol. 2017, 429, 1903-1920. [CrossRef] [PubMed]

170. Shen, R.; Han, W.; Fiorin, G.; Islam, S.M.; Schulten, K.; Roux, B. Structural Refinement of Proteins by Restrained Molecular Dynamics Simulations with Non-interacting Molecular Fragments. PLoS Comput. Biol. 2015, 11, e1004368. [CrossRef] [PubMed]

171. Vicente, E.F.; Sahu, I.D.; Costa-Filho, A.J.; Cilli, E.M.; Lorigan, G.A. Conformational changes of the HsDHODH N-terminal Microdomain via DEER Spectroscopy. J. Phys. Chem. B 2015, 119, 8693-8697. [CrossRef] [PubMed]

172. Georgieva, E.R.; Borbat, P.P.; Norman, H.D.; Freed, J.H. Mechanism of influenza A M2 transmembrane domain assembly in lipid membranes. Sci. Rep. 2015, 5, 11757. [CrossRef] [PubMed]

173. Georgieva, E.R. Nanoscale lipid membrane mimetics in spin-labeling and electron paramagnetic resonance spectroscopy studies of protein structure and function. Nanotechnol. Rev. 2017, 6, 75-92. [CrossRef] 
174. Dixit, M.; Kim, S.; Matthews, G.F.; Erreger, K.; Galli, A.; Cobb, C.E.; Hustedt, E.J.; Beth, A.H. Structural Arrangement of the Intracellular Ca2+ Binding Domains of the Cardiac Na+/Ca2+ Exchanger (NCX1.1): Effects of Ca2+ binding. J. Biol. Chem. 2013, 288, 4194-4207. [CrossRef] [PubMed]

175. Hilger, D.; Polyhach, Y.; Jung, H.; Jeschke, G. Backbone Structure of Transmembrane Domain IX of the Na+/Proline Transporter PutP of Escherichia coli. Biophys. J. 2009, 96, 217-225. [CrossRef]

176. Kroncke, B.M.; Van Horn, W.D.; Smith, J.; Kang, C.; Welch, R.C.; Song, Y.; Nannemann, D.P.; Taylor, K.C.; Sisco, N.J.; George, A.L.; et al. Structural basis for KCNE3 modulation of potassium recycling in epithelia. Sci. Adv. 2016, 2, e1501228. [CrossRef]

177. Barrett, P.J.; Song, Y.; Van Horn, W.D.; Hustedt, E.J.; Schafer, J.M.; Hadziselimovic, A.; Beel, A.J.; Sanders, C.R. The Amyloid Precursor Protein Has a Flexible Transmembrane Domain and Binds Cholesterol. Science 2012, 336, 1168-1171. [CrossRef] [PubMed]

178. Mullen, A.; Hall, J.; Diegel, J.; Hassan, I.; Fey, A.; Macmillan, F. Membrane transporters studied by EPR spectroscopy: Structure determination and elucidation of functional dynamics. Biochem. Soc. Trans. 2016, 44, 905-915. [CrossRef] [PubMed]

179. Basak, S.; Schmandt, N.; Gicheru, Y.; Chakrapani, S. Crystal structure and dynamics of a lipid induced potential desensitized-state of a pentameric ligand-gated channel. Elife 2017, 6, e23886. [CrossRef]

180. Herneisen, A.L.; Sahu, I.D.; McCarrick, R.M.; Feix, J.B.; Lorigan, G.A.; Howard, K.P. A Budding-Defective M2 Mutant Exhibits Reduced Membrane Interaction, Insensitivity to Cholesterol, and Perturbed Interdomain Coupling. Biochemistry 2017, 56, 5955-5963. [CrossRef]

181. Kumar, P.; Van Son, M.; Zheng, T.; Valdink, D.; Raap, J.; Kros, A.; Huber, M. Coiled-coil formation of the membrane-fusion K/E peptides viewed by electron paramagnetic resonance. PLoS ONE 2018, 13, e0191197. [CrossRef] [PubMed]

182. Louis, J.M.; Baber, J.L.; Ghirlando, R.; Aniana, A.; Bax, A.; Roche, J. Insights into the Conformation of the Membrane Proximal Regions Critical to the Trimerization of the HIV-1 gp41 Ectodomain Bound to Dodecyl Phosphocholine Micelles. PLoS ONE 2016, 11, e0160597. [CrossRef] [PubMed]

183. Puljung, M.C.; DeBerg, H.A.; Zagotta, W.N.; Stoll, S. Double electron-electron resonance reveals cAMP-induced conformational change in HCN channels. Proc. Natl. Acad. Sci. USA 2014, 111, 9816-9821. [CrossRef] [PubMed]

184. Martens, C.; Stein, R.A.; Masureel, M.; Roth, A.; Mishra, S.; Dawaliby, R.; Konijnenberg, A.A.; Sobott, A.K.F.; Govaerts, C.; McHaourab, H.S. Lipids modulate the conformational dynamics of a secondary multidrug transporter. Nat. Struct. Mol. Biol. 2016, 23, 744-751. [CrossRef] [PubMed]

185. Riederer, E.A.; Focke, P.J.; Georgieva, E.R.; Akyuz, N.; Matulef, K.; Borbat, P.P.; Freed, J.H.; Blanchard, S.C.; Boudker, O.; Valiyaveetil, F.I. A Facile approach forte in vitro assembly of multimeric membrane transport proteins. Elife 2018, 7, e36478. [CrossRef] [PubMed]

186. Georgieva, E.R.; Borbat, P.P.; Ginter, C.S.; Freed, J.H.; Boudker, O. Conformational ensemble of the sodium-coupled aspartate transporter. Nat. Struct. Mol. Biol. 2013, 20, 215-221. [CrossRef] [PubMed]

187. Nyenhuis, D.A.; Nilaweera, T.D.; Cafiso, D.S. Native Cell Environment Constrains Loop Structure in the Escherichia coli Cobalamin Transporter BtuB. Biophys. J. 2020, 119, 1550-1557. [CrossRef] [PubMed]

188. Sahu, I.D. Conformational Dynamics of the Extracellular Loop of BtuB in Whole Cells. Biophys. J. 2020, 119, 1470-1471. [CrossRef] 